MANCHESTER

1824

命这

Economics

Discussion Paper Series

EDP-1013

\title{
Are antidumping duties an antidote for predation?
}

\author{
James Gaisford \\ Shan (Victor) Jiang \\ Stefan Lutz
}

July 2010

Economics

School of Social Sciences

The University of Manchester

Manchester M13 9PL 


\title{
ARE ANTIDUMPING DUTIES AN ANTIDOTE FOR PREDATION? ${ }^{\dagger}$
}

\author{
James Gaisford, * \\ Shan (Victor) Jiang, ${ }^{* *}$ \\ Stefan Lutz ${ }^{* * *}$
}

\begin{abstract}
Since price discrimination and selling below cost arise in the normal course of business and are usually legal for home firms, countering these practices by foreign firms provides a very weak rationale for antidumping duties. If antidumping duties were to provide a systematic defense against predation by foreign firms, however, a strong "fair-trade" justification would remain. This paper adapts the classic entry-deterrence analysis of Dixit (1979) and Brander and Spencer (1981) to provide a simple treatment of predation, which is applicable with price leadership as well as quantity leadership. Although situations of cross-border predation appear to be quite rare, foreign firms may sometimes find themselves in leadership positions if they have to make shipments and/or set prices before their home rivals. This paper shows that, in the context of such an international leadership game, predation may occur without dumping and visa versa. Further, when dumping and predation do coexist, a sophisticated form of antidumping duty would prevent predation, but the simple antidumping duties that are generally observed in practice will often be insufficient. Consequently, the paper challenges the "fair-trade" view of antidumping policy as an antidote for predation and strengthens the foundation of the counter-argument that antidumping constitutes a new insidious form of protectionism and trade harassment, which is of particularly serious concerns for small countries.
\end{abstract}

JEL classification: F12, F13, L13

Keywords: trade, duopoly, Stackelberg, Cournot, antidumping, predation

\footnotetext{
${ }^{\dagger}$ The views expressed in this paper are those of the authors and do not necessarily reflect those of the institutions they are affiliated with. Lutz thanks the International Centre for Economic Research (ICER), Torino, Italy for support. We also thank conference participants at CEA 2008 and WEAI 2009 in Vancouver and seminar participants at the Universidad Complutense de Madrid and the University of Manchester.

* Corresponding author: Professor of Economics, University of Calgary. Address: Department of Economics, 2500 University Drive NW, Calgary, Alberta CANADA T2N 1N4. Phone: 1-403-220-3157. Fax: 1-403-282-

5262. E-mail: gaisford@ucalgary.ca

** PhD Candidate, University of Calgary

*** Research Fellow, University of Manchester
} 


\section{Introduction}

The declared intent of antidumping policy is to protect home industries from unfair competitive practices by foreign firms. In practice, according to the World Trade Organization (WTO) antidumping Agreement, price-based dumping occurs when the foreign firm sells at lower price in the home country market than in the foreign market, while costbased dumping occurs when the foreign firm sells at a price lower than its average cost in the home country market. When there is an evidence of both dumping and material injury to the home industry, the home country may implement antidumping duties, which eliminate the dumping margin. ${ }^{1}$ Antidumping policies have become extremely controversial. In recessionary periods, home firms may frequently sell at prices less than average cost without fear of sanctions, while their foreign counterparts may face antidumping duties. Further, many, though not all, forms of price discrimination are fully legal for home firms within the home market. While it is, thus, hard to argue that price discrimination or selling below average cost is unfair per se, proponents of antidumping policy frequently argue that recourse to punitive tariffs is necessary to prevent blatantly unfair predatory practices by foreign firms. This paper investigates whether antidumping duties are likely to be a reasonable antidote when there is a threat of predation by foreign firms.

Concerns over possible predation by foreign firms have a long history. For example, according to Viner (1931, p. 51-64), in the early twentieth century the evidence seems to suggest that Germany systematically undertook dumping in a variety of industries, because large-scale cartels in Germany shared dumping costs while high tariffs in Germany prevented foreign competitors from lowering the high home prices. Many countries, thus, adopted antidumping measures against large German cartels, which were accused of eliminating competition in their home markets. In the 1980s, Japan began to dominate the semiconductor industry by charging low prices in international markets (Baldwin 1994). The U.S. government alleged, somewhat problematically, that dumping by Japanese firms was forcing American semiconductor producers out of business and, thus, an antidumping action was initiated against Japanese semiconductor industry.

\footnotetext{
${ }^{1}$ The WTO antidumping Agreement sets forth procedural requirements for the implementation of antidumping measures, including the calculation of the extent of dumping and the determination of injury. Further, once antidumping duties are in place, the authorities may conduct periodic reviews of the antidumping measures on their own initiatives or upon request home firms. Antidumping duties normally terminate no later than five years after first being applied, unless a review investigation prior to that date establishes that expiry of the duty would be likely to lead to continuation or resumption of dumping and injury.
} 
Questions concerning the efficacy of antidumping policy are becoming increasingly important at present as the use of such measures proliferate. Before the WTO antidumping Agreement came into effect in 1995, antidumping measures were implemented primarily by a small number of developed countries including the U.S., Australia, the E.U., and Canada (see Prusa, 2001, 595, Table 1). In contrast, since 1995 many developing countries, such as Argentina, Brazil, China, India, and South Africa, have enacted antidumping legislation and have become frequent users of antidumping measures according to the WTO website. WTO statistics also reveal that the average number of new antidumping duties implemented per year by WTO members increased by over $80 \%$ from 88 in the period of 1987-1994 to 162 in the period of 1995-2006. The upward trend in the use of antidumping measures is shown in Fig. 1. Among a total of 1,940 antidumping measures reported to the WTO from 1995 to 2006, there were several prominent new users as well as traditional users in the "top" group of countries: India (331), the U.S. (239), the E.U. (231), Argentina (150), South Africa (120), Canada (87), Australia (71), and Brazil (66). Over the same period, the most frequent target of anti dumping measures was China (375) followed by South Korea (136), Taiwan (106), the U.S. (104) and Japan (97). In addition, the sectors most affected by antidumping actions were: base metals (31\%), chemicals (20\%), plastics (13\%), textiles (8\%), machinery and equipment (8\%) and pulp of wood (4\%).

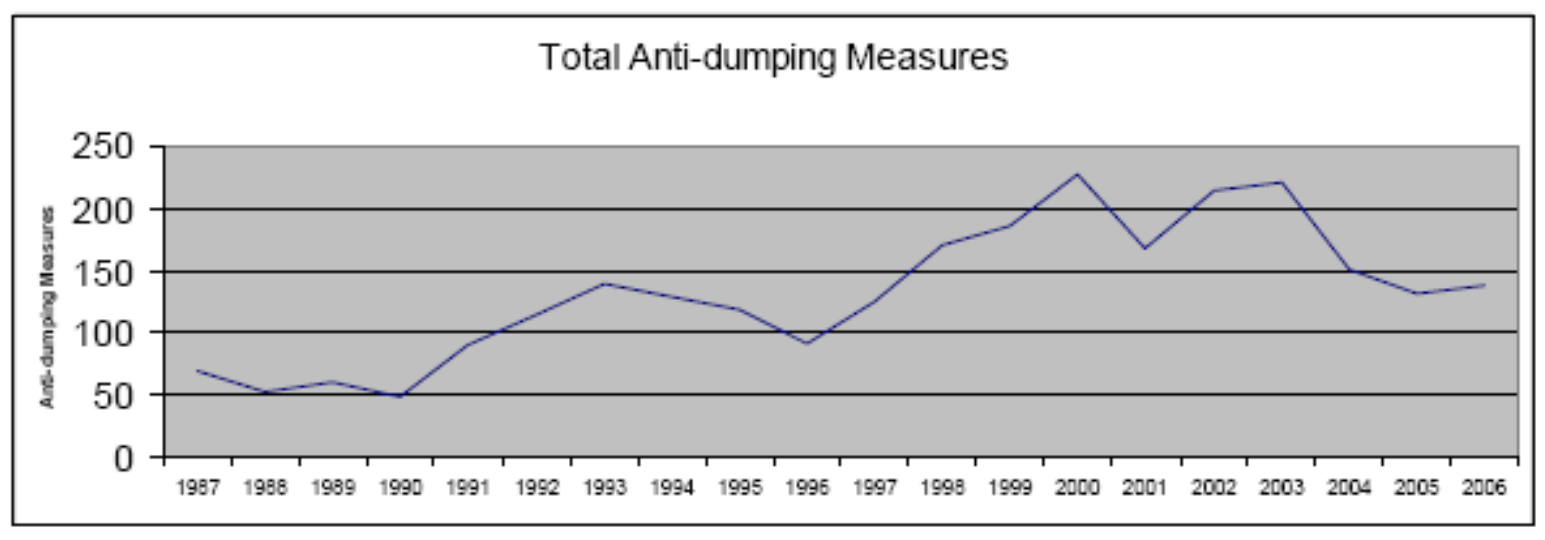

Figure 1: The poliferation of antidumping measures

Source: WTO Secretariat, Rules Division antidumping Measures Database

To address the issue of whether antidumping duties provide a solid defense against predation by foreign firms, we adapt the Stackelberg entry deterrence model, pioneered by Dixit (1979) and Brander and Spencer (1981) to provide a simple one-period analysis of predation. The foreign firm is assumed to be a monopoly in the foreign market, but it plays a quantity-setting game with its home-firm rival in the home-country market. Further, we consider the interesting, though likely infrequently occurring, situation where the foreign firm is a first 
mover by virtue of having to ship goods before the home firm. The foreign firm may use this position to force the home firm out of the market or to accommodate participation of the home firm. Such "predatory behaviour" by the foreign firm is clearly harmful to the home firm and may be perceived as unfair. Higher marginal costs for the foreign firm increase the relative attractiveness of accommodation. Thus, in situations where the foreign firm would engage in predation, a sufficiently high anti-predation tariff could be levied to induce accommodation and allow the participation of the home firm.

This paper shows that under some circumstances, an antidumping duties would be implemented in the absence of predation, and under other circumstances, no dumping duty would be imposed in the presence of predation. Even if both predation and dumping by foreign firms coexist, a standard antidumping duty, of the type used in practice, may not be sufficient to preclude predation. The reason is that the height of the anti-predation tariff relies only on the home market conditions, while the height of an antidumping duty depends on both the home and foreign market conditions. Interestingly, when predation and dumping coexist, a sophisticated antidumping duty, which anticipates firm behaviour and eliminates dumping in a single iteration, can prevent predation in those cases where the foreign firm produces a limit quantity just large enough to keep the home firm out of the market. The onerous computational requirements of such sophisticated antidumping duties coupled with the need for dumping and limit-quantity predation to initially coexist, however, vitiate the practical importance of this result. These overall results of this modeling exercise, therefore, suggest that antidumping duties cannot be justified as a policy mechanism to prevent predatory behavior by foreign firms.

In addition, to being harmful to the home firm, predation is typically thought to be harmful to national welfare in the foreign country since there are fewer firms in the market. Consequently, we also extend welfare analysis in Brander and Spencer (1981) to address two new questions. First, we examine whether home-country welfare unambiguously declines if the foreign firm chooses predation rather than accommodating the participation of the home firm. We conclude that predation by foreign firms may not be welfare reducing. To preempt participation of the home firm, the foreign firm must sell a larger quantity of its product than it would do to accommodate participation. The extra quantity lowers the price of the foreign product, and could raise the overall consumer surplus. If this gain in consumer surplus outweighs the lost profit of the home firm, the home country gains from predation. Second, we investigate whether the home country unambiguously gains from imposing its anti- 
predation tariff. Even with the addition of home country tariff revenue, there remains an inherent ambiguity concerning the impact on home-country welfare.

There is a strand of previous literature that has explored predatory actions in an international context. Eaton and Mirman (1991) show that when the home firm has imperfect information on the state of demand in the foreign market where the foreign firm is a monopolist, the foreign firm may engage in signal-jamming by means of "predatory dumping" or overshipping to the home market in the first period of a two period game so as to garner a greater market share in the home market in the second period. Hartigan (1994) explores a pricesetting game where the home firm cannot observe whether the foreign firm has high or low marginal costs. Given that the home firm will exit after the first period due to negative profits if it is faced with a low cost foreign firm, the foreign firm may have an incentive to engage in signal-jamming by mimicking a low-cost, low-price firm in the first period so as to reap monopoly profits in the second period. In Harigan (1996), predatory dumping may also arise when capital markets in the home country are imperfect and will not lend to a home firm to keep it solvent after the first period. In the Hartigan (1994 and 1996) articles, antidumping policy may increase the costs of predatory dumping and, thereby, diminish the probability of its occurrence.

We build on this literature in two important directions. First we show that the foreign firm may preempt the participation of the home firm and engage in predation even in the presence of full information and perfect capital markets. In our model, the simple presence of economies of scale in production arising from quasi-fixed costs act as an impediment to participation by the home firm and provide an opportunity for predation by the foreign firm. Second, we also demonstrate that antidumping policy, as currently configured, provides a weak defense against such predation at best.

The rest of the paper is organized as follows. Section 2 presents a simple model quantity leadership, which generates possible predatory equilibria as well as conventional Stackelberg equilibria. In section 3, we investigate how the choice of tariffs affects the leadership behaviour of the foreign firm and the resulting equilibrium. Thereafter, in section 4 we determine the tariff that is just sufficient to prevent predation and then, in section 5, we compare the anti-predation tariff with standard and sophisticated antidumping duties. Section 6 analyses the impact of predation and predation-preventing tariffs on national welfare and then section 7 provides concluding remarks. Appendices provide technical details on the 
quantity-leadership game and outlines a price leadership game, which gives broadly similar results.

\section{A Simple Model of International Predation}

Suppose that two firms are potential participants in an oligopoly game by merit of having previously incurred sunk costs. On the basis of ex ante expectations, the first firm, which is located in the foreign country, has invested $\psi_{f}^{h f}$ on research and development and product adaptation enabling it to participate in the home market as well as the foreign market. Meanwhile the second firm, which is located in the home country, has invested $\psi_{h}^{h}$ on research and development allowing it to participate only in the home market. We assume that two markets are segmented because of trade barriers, such as transport costs. At the start of the game, demand, production cost and transport cost parameters are revealed and become common knowledge. Since the realized parameters may differ from those that were expected when sunk costs were incurred, a firm may regret having incurred its sunk cost to become a potential participant, and indeed, it may elect not to participate. Although the previous literature on predatory dumping frequently assumes forms of imperfect information (see Eaton and Mirman (1991), and Hartigan (1994)), we show that predation may arise in a perfect-information framework.

After the state of the world is revealed, the government in the home country or more aptly its antidumping administration has the prerogative to set a tariff. For the most part, we assume that the government will choose to levy a tariff if there is a perceived threat of predation on the one hand or of dumping on the other hand. It is assumed once a tariff is set, it is not subject to later revision and it remains in place whatever the behavior of the foreign firm. Consequently the specific tariff, $t$, becomes the key policy parameter in the model and we focus on comparisons between anti-predation and anti-dumping settings of $t .^{2}$

Finally, after any tariff is implemented, a one-shot quantity-leadership game is played in the home-country market where the foreign firm is assumed to be a quantity leader because its product must be shipped first. While such leadership situations may be infrequent in practice, they open the door to predatory behavior and, thus, still warrant careful consideration. As we

\footnotetext{
${ }^{2}$ The model could be expanded to allow for tariffs, which are contingent on either predatory or dumping behavior by the foreign firm and equal to zero in the absence of such behavior. Initial work in this direction suggests that qualitatively similar results would be obtained.
} 
will see, the leader-follower structure implies that, even in the static setting, the foreign firm may engage in predatory behavior that preempts the participation of the home firm purely on the basis of maximizing single-period profits. Thus, higher monopoly returns in the future are neither necessary nor sufficient for predation to occur in the present. ${ }^{3}$ Little additional complexity arises when we assume that the two firms produce differentiated products, and this facilitates comparison with the price-leadership variant of the model, which is presented in the appendix. While the main results of the price-setting game are similar to those of the quantity-setting game, the differences between two models will be mentioned in the text.

To simplify comparative statics, we assume linear inverse demands and constant marginal costs. ${ }^{4}$ In the region of quantity space where prices are positive, the demand functions in the home market are:

$$
\begin{aligned}
& p_{f}^{h}=\alpha-\beta q_{f}^{h}-\gamma q_{h}^{h} \\
& p_{h}^{h}=\theta-\sigma q_{h}^{h}-\gamma q_{f}^{h}
\end{aligned}
$$

where the subscripts $f$ and $h$ indicate the foreign firm and home firm respectively; the superscripts $f$ and $h$ represent the foreign market and home market; $p$ denotes price and $q$ represents sales. With the respect to the demand parameters, $\beta>0, \sigma>0$, and $\beta \sigma \geq \gamma^{2}$ so that the underlying utility function is concave. We also assume that $\gamma>0$ so the products are at least imperfect substitutes and that $\alpha>0$ and $\theta>0$ so that both varieties are desirable to consumers. Given that the home firm does not participate in the foreign market, the inverse demand function for that market is simply:

$$
p_{f}^{f}=\alpha^{f}-\beta^{f} q_{f}^{f}
$$

Production exhibits a simple form of economies of scale. We assume that a minimum startup amount of labor must be in place before any output is produced giving rise to quasi-fixed costs given by $\phi_{h}$ and $\phi_{f}$ for the home and foreign firm respectively. Since these quasi-fixed costs serve as a potential barrier to participation, we refer to them as participation costs. Once the startup labor is in place, a constant additional amount of labor is needed to produce each unit of output. Consequently, the foreign and home firms incur constant marginal costs, given by $c_{h}$ and $c_{f}$. Assuming constant marginal cost for the foreign firm simplifies the analysis

\footnotetext{
${ }^{3}$ Of course, in a repeated-game extension of the model, the rewards of future monopoly may act as an additional incentive for predation in the present period.
} 
since its sales in the two markets remain independent and do not affect each other through rising or falling marginal costs. ${ }^{5}$ The foreign firm also faces trade barriers on shipments to the home market. In addition to the specific tariff, $t$, a transport cost parameter, $\tau$, arises because a constant amount of labor is required to ship each unit of the product.

The operating profits (exclusive of sunk costs) of the foreign firm selling in both the home and foreign markets, and the operating profits of the home firm, only serving the home market, are simply revenues minus costs.

$$
\begin{gathered}
\Pi_{f}= \begin{cases}0, & \text { if } q_{f}^{h}=0 \text { and } q_{f}^{f}=0 \\
p_{f}^{h} q_{f}^{h}-\left[c_{f}+\tau+t\right] q_{f}^{h}+p_{f}^{f} q_{f}^{f}-c_{f} q_{f}^{f}-\phi_{f}, & \text { if } q_{f}^{h}>0 \text { or } q_{f}^{f}>0\end{cases} \\
\Pi_{h}= \begin{cases}0, & \text { if } q_{h}^{h}=0 \\
p_{h}^{h} q_{h}^{h}-c_{h} q_{h}^{h}-\phi_{h}, & \text { if } q_{f}^{h}>0\end{cases}
\end{gathered}
$$

Setting the quasi-fixed participation costs aside momentarily, the variable profit of the foreign firm in the home market is $\pi_{f}^{h}=p_{f}^{h} q_{f}^{h}-\left[c_{f}+\tau+t\right] q_{f}^{h}$, and the variable profit of the home firm in the home market is $\pi_{h}^{h}=p_{h}^{h} q_{h}^{h}-c_{h} q_{h}^{h}$. For reference purposes, we note that the standard Cournot reaction functions based on these variable profits would be written as:

$$
\begin{aligned}
& q_{f}^{h}=\frac{\alpha-\gamma q_{h}^{h}-c_{f}}{2 \beta} \\
& q_{h}^{h}=\frac{\theta-\gamma q_{f}^{h}-c_{h}}{2 \sigma}
\end{aligned}
$$

Participation costs introduce the possibility of discontinuities in these reaction functions. For discussion purposes, however, we assume that the foreign firm obtains sufficiently high variable profits on its own market to overcome its participation costs, $\phi_{f}$. Consequently, the foreign firm will always participate in the foreign market, and its participation costs will not prevent it from operating in the home market.

By contrast, the participation costs of the home firm, $\phi_{h}$, do act as a barrier to its participation in the home market, which may be used by the foreign firm to preempt participation of the home firm. Given the presence of participation costs, the home firm's reaction function is

\footnotetext{
${ }^{4}$ Allowing for non-linear demands does not alter our main results.

${ }^{5}$ In contrast, a market connection through increasing marginal costs is central to the analysis of predatory dumping in Eaton and Mirman (1991).
} 
discontinuous. In Fig. 2, which is based on Dixit (1979), $B_{f}^{h}$ is the 'limit' quantity for the foreign firm where the home firm is indifferent between participating and staying out of the home market. That is to say, at point A the home firm's operating profits are equal to zero by virtue of the participation cost. If the foreign firm's sales are higher than $B_{f}^{h}$, the home firm has negative profit and stays out of the home market. If the foreign firm's sales are lower than $B_{f}^{h}$, it is profitable for the home firm to operate in the home market. Thus, over the range of foreign sales from zero to $B_{f}^{h}$, the home firm has a regular downward-sloping Cournot reaction function. In Fig. 2, the line segments $M_{h}^{h} A$ and $B_{f}^{h} \bar{q}_{f}^{h}$ including the end points of both segments indicate the home firm's reaction function. Here, $\bar{q}_{f}^{h}$ represents the maximum possible limit quantity, which would apply in the case where the home firm's participation costs were equal to zero. We will always assume that both $M_{h}^{h}$ and $B_{f}^{h}$ are strictly positive so that the home firm will participate in the home market for sufficiently low values of $q_{f}^{h}$ on the interval $\left[0, B_{f}^{h}\right]$. Given that $M_{h}^{h}>0$, it follows that $\bar{q}_{f}^{h}>0$ as well.

Since we assume that the foreign firm has to ship its goods to the home market before the home firm, there is a quantity-leadership game, rather than a simultaneous quantity game in the home market. Consequently, as shown in Fig 2, the home firm is a Stackelberg follower, which maximizes its profits in accordance with its Cournot reaction function, given the foreign firm's shipments to the home market. The shipment decision of the foreign firm hinges on its own profits. In the home market, the foreign firm can preempt participation by producing slightly more than the limit output $B_{f}^{h}$, or accommodate participation at the Stackelberg point, $S$, by selling $S_{f}^{h}$. The profits of the foreign firm are larger, on iso-profit contours that are closer to its pure monopoly point $M_{f}^{h}$. Notice that the foreign firm is indifferent between selling at the output pair $\left(Z_{f}^{h}, 0\right)$ on the iso-profit contour $C S Z_{f}^{h}$ in Fig. 2, and selling at $\left(S_{f}^{h}, S_{h}^{h}\right)$. For reasons, which will become clear, we refer to $Z_{f}^{h}$ as the Stackelberg trigger output. 


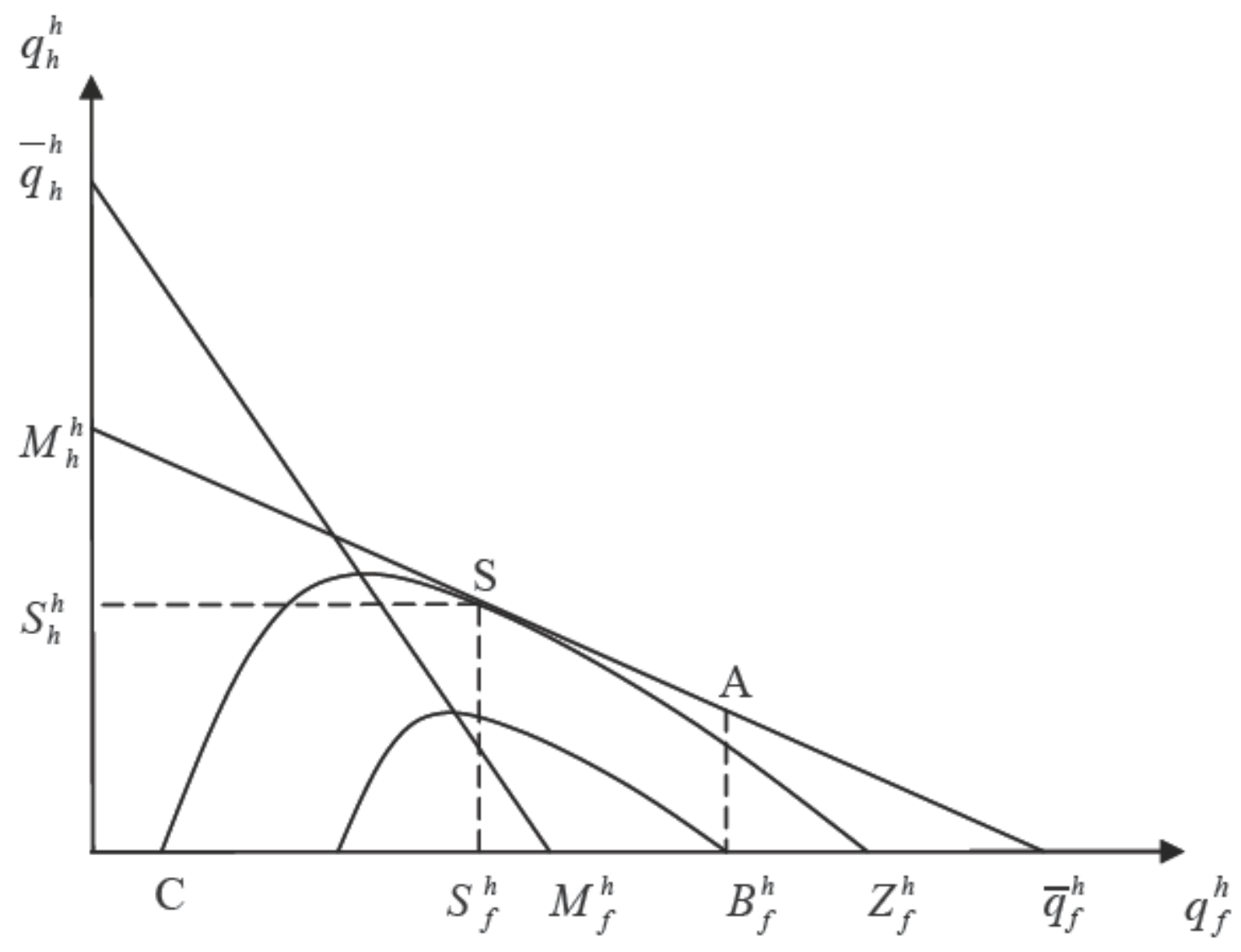

Figure 2: Reaction Functions

The following proposition based on Dixit (1979) overviews the types of equilibria, which arise in the model.

Proposition 1 (Dixit) The following types of equilibria are possible:

1. Accommodation: If $B_{f}^{h} \geq Z_{f}^{h}$, then the foreign firm accommodates participation by leading $q_{f}^{h}=S_{f}^{h}$, while the home firm follows with $q_{h}^{h}=S_{h}^{h}$.

2. Predation: If $Z_{f}^{h}>B_{f}^{h} \geq M_{f}^{h}$, then the foreign firm preempts participation and sells just above the limit quantity such that $q_{f}^{h}=B_{f}^{h}+\varepsilon$.

3. Monopolization: If $M_{f}^{h}>B_{f}^{h}$, then the foreign firm monopolizes the home market and sells the monopoly quantity, $q_{f}^{h}=M_{f}^{h}$. 
In the accommodation scenario, which is different from that shown in Fig. 2, the home firm's participation costs are low and the limit output, $B_{f}^{h}$, is greater than or equal to the Stackelberg trigger output $Z_{f}^{h}$. In this case, there would be a traditional Stackelberg equilibrium because the foreign firm attains higher profit by selling $S_{f}^{h}$ than it would if it preempted participation by leading an output slightly larger than $B_{f}^{h}$.

In the predation scenario, which is the one shown in Fig. 2, the home firm encounters moderate participation costs such that the trigger output is strictly larger than the limit output and the limit output is at least as large as the monopoly output (i.e., $Z_{f}^{h}>B_{f}^{h} \geq M_{f}^{h}$ ). In this case, the profit that the foreign firm earns when shipping slightly more than $B_{f}^{h}$ is higher than the profit obtained from accommodating participation at the Stackelberg equilibrium $S$ as shown by the inner iso-profit contour. This profit is also higher than when the foreign firm sells quantities significantly larger than $B_{f}^{h}{ }^{6}$ The foreign firm, thus, is willing to sell a quantity marginally greater than $B_{f}^{h}$ to preempt the participation of the home firm. Such situations where the best strategy for the foreign firm is to preempt participation by the home firm will be said to constitute predation by the foreign firm. This definition of predation is logical. If the foreign firm raises its output from the Stackelberg level to slightly above the limit level, there is a persuasive argument that an otherwise viable home firm has been pushed out of the market.

In the monopolization scenario, which differs from Fig. 2, the home firm has high participation costs such that $M_{f}^{h}>B_{f}^{h}$. In this case, the foreign firm can attain its highest profit in the home market by selling at its monopoly output $M_{f}^{h}$. In this scenario, the foreign firm monopolizes the home market since the home firm's profit would be negative if it participated. It should be observed that we have excluded the monopoly case from our definition of predation. If the home firm can do no better than to stay out of the home market

\footnotetext{
${ }^{6}$ If the foreign firm sells at $B_{f}^{h}$, the home firm is indifferent between participating at A or staying out at $B_{f}^{h}$. Nevertheless, the decision to participate by the foreign firm will significantly lower the foreign firm's profit. The expected profit for the foreign firm with a positive probability of participation is smaller than the profit of preempting participation with an output marginally higher than $B_{f}^{h}$. Consequently, it is reasonable that the foreign firm sells the quantity marginally greater than $B_{f}^{h}$ instead of $B_{f}^{h}$.
} 
when the foreign firm chooses to sell at its monopoly point, then the home firm is simply not sustainable.

Although the price-leadership game discussed in the appendix has different, somewhat more complex reaction functions, the reaction function for the home firm is still discontinuous due to its participation costs. Accordingly, predation can occur in the price-leadership game as well, and we obtain results similar to Prop. 1.

\section{The Impact of Tariffs}

Although Dixit (1979) shows that Prop. 1 generally holds regardless of functional forms, we can solve the model mathematically based on linear demands and constant marginal costs for any particular level of tariffs. In a subsequent step, we can then analyze the effects associated with tariff changes. Regardless of the situation in the home market, the foreign firm always sells at its monopoly quantity on the foreign market such that $M_{f}^{f}=\left[\alpha^{f}-c_{f}\right] /\left[2 \beta^{f}\right]$.

We can also solve for the foreign firm's monopoly output in the home market using its own reaction function given by Eq. (6):

$$
M_{f}^{h}=\left\{\begin{array}{ll}
0, & \text { if } t \geq 2 \beta \mu \\
\mu-t / 2 \beta, & \text { if } t<2 \beta \mu
\end{array}\right. \text { (8) }
$$

where $\mu=\left[\alpha-\left[c_{f}+\tau\right]\right] /[2 \beta]$ represents the monopoly output of the foreign firm when tariffs are absent. For tariffs less than $2 \beta \mu$, there is a negative linear relationship between the tariff and the monopoly output of the foreign firm, which is shown by the AGHF line in Fig. 3.

Using the home firm's standard Cournot reaction function given by Eq. (7), we can also obtain the monopoly output of the home firm:

$$
M_{h}^{h}=\left[\theta-c_{h}\right] /[2 \sigma]
$$

which we assume is always positive. Next, we solve for the foreign firm's maximum limit output using the home firm's reaction function given by Eq. (7).

$$
\bar{q}_{f}^{h}=\frac{\theta-c_{h}}{\gamma}=\frac{2 \sigma}{\gamma} M_{h}^{h}>0
$$




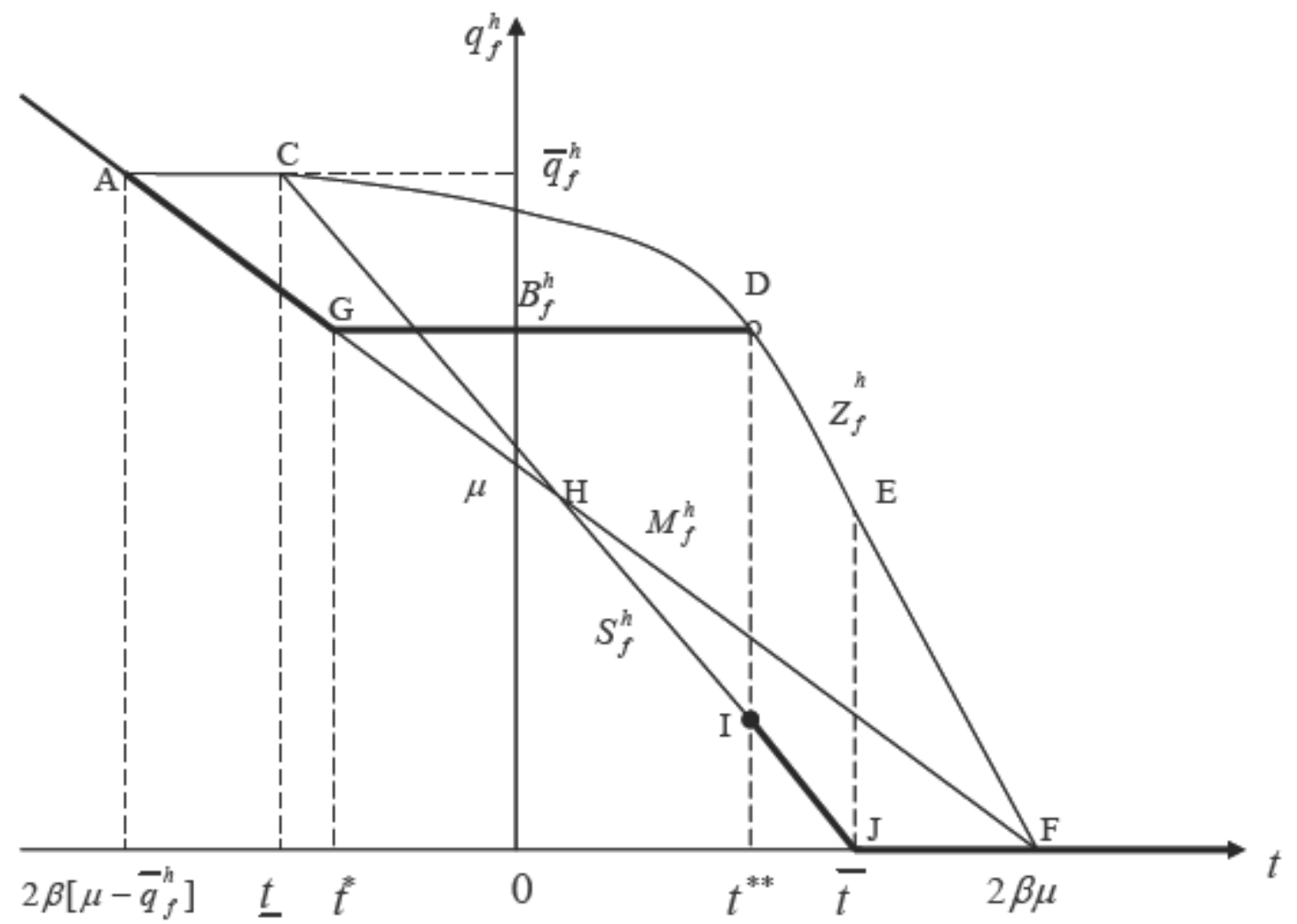

Figure 3: The impact of tariffs on shipments by the foreign firm

We can derive the limit output $B_{f}^{h}=\left[\theta-c_{h}-2 \sqrt{\sigma \phi_{h}}\right] / \gamma$ by setting the profit of the home firm equal to zero when this firm produces along its regular Cournot reaction function in Eq. (7).

$$
B_{f}^{h}=\left\{\begin{array}{lll}
0 & \text { if } & \phi_{h} \geq\left[\theta-c_{h}\right]^{2} /[4 \sigma] \\
\bar{q}_{f}^{h}-2 \sqrt{\sigma \phi_{h}} / \gamma & \text { if } & \phi_{h} \leq\left[\theta-c_{h}\right]^{2} /[4 \sigma]
\end{array}\right.
$$

If participation costs are absent, the limit output is at the maximum level such that $B_{f}^{h}=\bar{q}_{f}^{h}$. Of course, both the maximum limit output, $\bar{q}_{f}^{h}$, and the limit output, $B_{f}^{h}$, are independent of the tariff as shown in Fig. 3.

For an internal Stackelberg equilibrium, the leadership output of the foreign firm and the follower output of the home firm are as follows: ${ }^{7}$

$$
S_{f}^{h}=\frac{2 \sigma\left[\alpha-\left[c_{f}+\tau+t\right]\right]-\gamma\left[\theta-c_{h}\right]}{4 \beta \sigma-2 \gamma^{2}}
$$

\footnotetext{
${ }^{7}$ These Stackelberg outputs are obtained by maximizing foreign firm's profits given by Eq. (4) subject to the home firm's Cournot reaction function given by Eq. (7).
} 


$$
S_{h}^{h}=\frac{\left[2 \beta-\frac{\gamma^{2}}{2 \sigma}\right]\left[\theta-c_{h}\right]-\gamma\left[\alpha-\left[c_{f}+\tau+t\right]\right]}{4 \beta \sigma-2 \gamma^{2}}
$$

Making use of Eqs. (8) and (10) and allowing for the possibility of boundary equilibria leads to the following results.

$$
\begin{aligned}
& S_{f}^{h}= \begin{cases}0 & \text { if } t \geq \bar{t} \\
{\left[4 \beta \sigma M_{f}^{h}-\gamma^{2} \bar{q}_{f}^{h}\right] /\left[4 \beta \sigma-2 \gamma^{2}\right]} & \text { if } t \leq t \leq \bar{t} \\
\bar{q}_{f}^{h} & \text { if } 2 \beta\left[\mu-\bar{q}_{f}^{h}\right] \leq t \leq \underline{t} \\
M_{f}^{h} & \text { if } t \leq 2 \beta\left[\mu-\bar{q}_{f}^{h}\right]\end{cases} \\
& S_{h}^{h}=\left\{\begin{array}{lr}
M_{h}^{h} & \text { if } t \geq \bar{t} \\
\left\{\left[2 \beta \gamma-\frac{\gamma^{3}}{2 \sigma}\right] \bar{q}_{f}^{h}-2 \gamma \beta M_{f}^{h}\right\} /\left[4 \beta \sigma-2 \gamma^{2}\right] & \text { if } \underline{t} \leq t \leq \bar{t} \\
0 & \text { if } t \leq \underline{t}
\end{array}\right.
\end{aligned}
$$

Here, the high boundary tariff, $\bar{t}=\alpha-\left[c_{f}+\tau\right]-\gamma\left[\theta-c_{h}\right] /[2 \sigma]$, can be determined by setting $S_{f}^{h}=0$ in Eq. (12) and the low boundary tariff, $\underline{t}=\alpha-\left[c_{f}+\tau\right]-\left[4 \sigma \beta-\gamma^{2}\right]\left[\theta-c_{h}\right] /[2 \sigma \gamma]$, can be determined by setting $S_{f}^{h}=\bar{q}_{f}^{h}$. Since we can rewrite the expression for the low boundary tariff as $\underline{t}=\bar{t}-\left[2 \beta \sigma-\gamma^{2}\right]\left[\theta-c_{h}\right] /[\gamma \sigma]$ and we have the parameter restriction that $\beta \sigma \geq \gamma^{2}$, it follows that $\bar{t}>\underline{t}$. Both $\bar{t}$ and $\underline{t}$ could be positive, or both could be negative, or as shown in Fig. 3, $\bar{t}$ could be positive while $\underline{t}$ is negative. The foreign firm's Stackelberg leadership output is a linear decreasing function of the tariff over the range of tariffs, $\underline{t} \leq t \leq \bar{t}$, as shown by the line segment CHIJ in Fig. 3. The foreign firm's Stackelberg output, $S_{f}^{h}$, could be either smaller or larger than its monopoly output, $M_{f}^{h}$. Subtracting $M_{f}^{h}$ from the internal solution for $S_{f}^{h}$ in Eq. (14), we obtain $S_{f}^{h}-M_{f}^{h}=\gamma^{2}\left[2 \beta \sigma-\gamma^{2}\right]^{-1}\left[M_{f}^{h}-\bar{q}_{f}^{h} / 2\right]$. It is immediately clear that: (i) $M_{f}^{h}>S_{f}^{h}$ when $M_{f}^{h}<\bar{q}_{f}^{h} / 2$, (ii) $M_{f}^{h}=S_{f}^{h}$ when $M_{f}^{h}=\bar{q}_{f}^{h} / 2$, (iii) $M_{f}^{h}<S_{f}^{h}$ when $M_{f}^{h}>\bar{q}_{f}^{h} / 2$.

We can also solve for the foreign firm's Stackelberg trigger output, which is given by intersection between the Stackelberg iso-profit contour and the horizontal axis. 
Lemma 1 The trigger output $Z_{f}^{h}$ is given by Eq. (16), which is continuous in $t$ and decreases monotonically from $\bar{q}_{f}^{h}$ to 0 over the interval $\underline{t}<t<2 \beta \mu$.

$$
Z_{f}^{h}= \begin{cases}2 M_{f}^{h} & \text { if } t \geq \bar{t} \\ M_{f}^{h}+\sqrt{\left[M_{f}^{h}\right]^{2}-\left[1-\frac{\gamma^{2}}{2 \beta \sigma}\right]\left[S_{f}^{h}\right]^{2}} & \text { if } \quad \underline{t} \leq t \leq \bar{t} \\ \bar{q}_{f}^{h} & \text { if } 2 \beta\left[\mu-\bar{q}_{f}^{h}\right] \leq t \leq \underline{t} \\ M_{f}^{h} & \text { if } t \leq 2 \beta\left[\mu-\bar{q}_{f}^{h}\right]\end{cases}
$$

(Proof: see Appendix I)

In Fig. 3, the curve CDEF shows the trigger output for values of tariffs where $\underline{t}<t<2 \beta \mu$. It is clear from the construction of Fig. 2 that $Z_{f}^{h}$ is greater than $S_{f}^{h}$ or $M_{f}^{h}$ for any situation where there is an internal Stackelberg equilibrium.

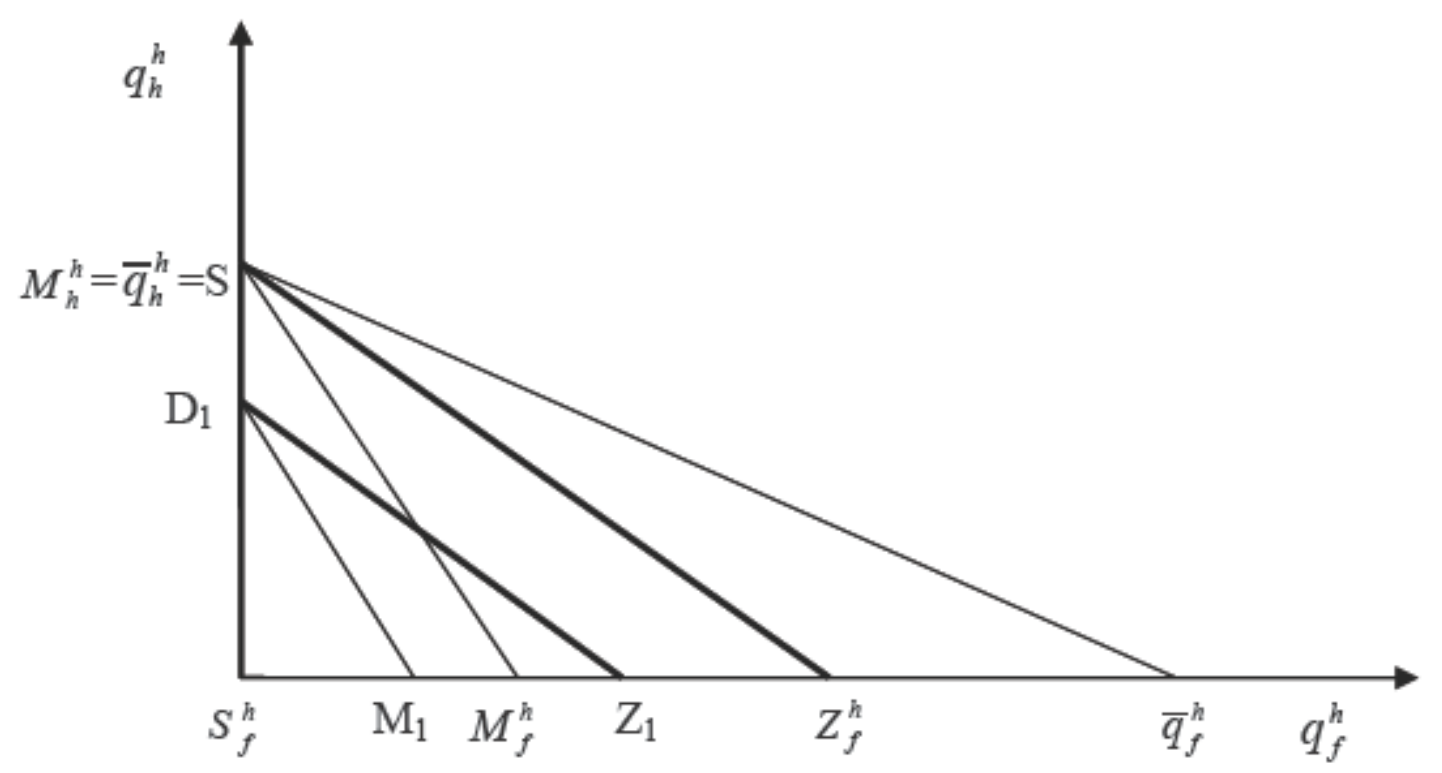

Figure 4: A boundary equilibrium with $S_{f}^{h}=0$ due to a prohibitive tariff

It is also worthwhile to examine situations where there are boundary Stackelberg equilibria in Eqs.(14), (15) and (16) in some depth. First consider the situation where $t \geq \bar{t}$. Suppose that the foreign firm's reaction function shown by $\bar{q}_{h}^{h} M_{f}^{h}$ in Fig. 2 shifts inwards, perhaps due to a higher tariff, such that $\bar{q}_{h}^{h}$ and $M_{h}^{h}$ coincide as shown in Fig. $4 .^{8}$ In this case, the zero iso-

${ }^{8}$ It is easy to confirm that when $M_{h}^{h}=\bar{q}_{h}^{h}, t=\bar{t}$, which just meets the requirement for the boundary 
profit contour for the foreign firm in the home market is given by the vertical axis where $q_{f}^{h}=0$ and the line segment $\bar{q}_{h}^{h} Z_{f}^{h}$. On the vertical axis, zero profit results from zero sales, while on the segment $\bar{q}_{h}^{h} Z_{f}^{h}$, the price of the foreign good is equal to the unit cost of exports (i.e., both the marginal and the average costs) such that its profit is equal to zero in the home market. Since the standard Cournot reaction function of the home firm is given by $M_{h}^{h} \bar{q}_{f}^{h}$, there is a boundary Stackelberg equilibrium at $S$. The foreign firm can not do better than leading with a quantity $S_{f}^{h}=0$ and earning zero profit on the home market. Consequently the home firm follows with $S_{h}^{h}=M_{h}^{h}$. When the foreign firm reaction function $\bar{q}_{h}^{h} M_{f}^{h}$ shifts in further to $D_{1} M_{1}$ in Fig. 4 due to a further increase in the tariff, the Stackelberg equilibrium remains at $S$, because this position is still consistent with zero profits for the foreign firm. Although we continue to have $S_{f}^{h}=0$ and $S_{h}^{h}=M_{h}^{h}, M_{f}^{h}$ moves toward the origin to $M_{1}$, and $Z_{f}^{h}=2 M_{f}^{h}$ moves toward the origin to $Z_{1}$. Consequently, the line segment $E F$ in Fig. 3 shows the trigger output in boundary situations where $\bar{t} \leq t<2 \beta \mu{ }^{9}$

Next consider the second boundary Stackelberg equilibrium that arises when $t \leq \underline{t}$. If the reaction function of the foreign firm given by $\bar{q}_{h}^{h} M_{f}^{h}$ in Fig. 2 were to shift outwards to a sufficient extent, say due to lower tariffs or higher import subsidies, an iso-profit contour for the foreign firm would be tangent to the regular Cournot reaction function of the home firm given by $M_{h}^{h} \bar{q}_{f}^{h}$ at the horizontal intercept (not shown in the figures). Consequently, there would be a boundary Stackelberg equilibrium where $S_{f}^{h}=Z_{f}^{h}=\bar{q}_{f}^{h}$ and $S_{h}^{h}=0$. Subsequent outward shifts of the foreign firm reaction function leave all facets of these boundary Stackelberg equilibrium unchanged until $M_{f}^{h}=\bar{q}_{f}^{h}$. Thereafter, further outward shifts of the foreign firm's reaction function displace the Stackelberg equilibrium along the horizontal axis such that $S_{f}^{h}=Z_{f}^{h}=M_{f}^{h}$ and $S_{h}^{h}=0$. The line segment $A C$ shows values of the Stackelberg

equilibrium.

${ }^{9}$ Provided that $\bar{t} \leq t<2 \beta \mu$, we have $Z_{f}^{h}=2 M_{f}^{h}>M_{f}^{h}>S_{f}^{h}=0$, but if $t \geq 2 \beta \mu$, then $Z_{f}^{h}=2 M_{f}^{h}=M_{f}^{h}=S_{f}^{h}=0$. 
leadership output, $S_{f}^{h}$, and the trigger output, $Z_{f}^{h}$, for the boundary equilibrium where $2 \beta\left[\mu-\bar{q}_{f}^{h}\right]<t \leq \underline{t}^{10}$

\section{Using tariffs to counteract predation}

Since a tariff raises the effective marginal cost of the foreign firm in the home market, tariffs could be used to prevent either monopoly or predation.

Proposition 2 Consider participation costs of the home firm that are positive but allow for the possible participation of the home firm such that $0<\phi_{h}<\left[\theta-c_{h}\right]^{2} /[4 \sigma]$.

1. There exists a unique (positive or negative) anti-monopoly tariff, $t^{*}$, such that $B_{f}^{h} \geq M_{f}^{h}$ if and only if $t \geq t^{*}$.

2. There exists a unique (positive or negative) anti-predation tariff, $t^{* *}>t^{*}$, such that $B_{f}^{h} \geq Z_{f}^{h}$ if and only if $t \geq t^{* *}$.

(Proof: see Appendix I)

Fig. 3 illustrates the results of Prop. 2. For the value of limit output, $B_{f}^{h}$ arising from the home firm's participation costs, if $t<t^{*}$, the foreign firm monopolizes the market with shipments determined by the line segment $A G$. If $t^{*} \leq t<t^{* *}$, there is a predatory behavior by the foreign firm, which produces an output slightly above $B_{f}^{h}$. The figure is shown for the parameter values such that predation exists when $t=0$. Finally, if $t \geq t^{* *}$ the foreign firm accommodates participation by the home firm. When the tariff reaches $t^{* *}$, there is a discrete decline in output from $D$ to $I$ as the foreign firm accommodates the participation of the home firm. For tariffs on the interval from $t^{* *}$ to $\bar{t}$ the line $I J$ shows the shipment of the foreign firm. For tariffs at $\bar{t}$ or above, the leadership output of the foreign firm is equal to zero. While the figure shows a case where the high boundary tariff, $\bar{t}$, happens to exceed the

\footnotetext{
${ }^{10}$ Provided that $2 \beta\left[\mu-\bar{q}_{f}^{h}\right]<t \leq \underline{t}$, we have $Z_{f}^{h}=S_{f}^{h}=\bar{q}_{f}^{h}>M_{f}^{h}$, but if $t \leq 2 \beta\left[\mu-\bar{q}_{f}^{h}\right]$, then $Z_{f}^{h}=S_{f}^{h}=M_{f}^{h} \geq \bar{q}_{f}^{h}$.
} 
anti-predation tariff, $t^{* *}$, and the anti-monopoly tariff, $t^{*}$, for higher levels of participation costs and thus lower levels of the limit output, it is possible to have $t^{* *}>\bar{t}>t^{*}$ or even $t^{* *}>t^{*}>\bar{t}$. This implies that if the home government imposes an anti-predation tariff, there are situations where the foreign firm will immediately accommodate the participation of the home firm by leading with an output that is equal to zero, rather than positive. In other words, an anti-predation tariff may not be prohibitive in some circumstances, but it will be in other circumstances.

Since a tariff raises the effective marginal cost of the foreign firm in the home market, Prop. 2 reveals that the home government can levy a tariff high enough to preclude predation. Moreover, in the price-leadership game, the similar proposition applies, because this result relies primarily on Prop. 1.

While the analysis has been primarily concerned about tariffs and quantities, which the foreign firm ships, it is important to also consider the implications for pricing by the foreign firm.

Proposition 3 Changes in the tariff affect the price of the foreign product as follows:

1. Monopolization: If the foreign firm monopolizes the home market because $t<t^{*}$, then the foreign firm's price is increasing in the tariff, such that $d p_{f}^{h} / d t>0$.

2. Predation: If the foreign firm preempts the participation of the home firm because $t^{*} \leq t<t^{* *}$, then the foreign firm's price remains constant as the tariff increases such that $p_{f}^{h}=p_{f}^{h}\left(B_{f}^{h}, 0\right)-\varepsilon=p_{f}^{h}\left(M_{f}^{h}\left(t^{*}\right), 0\right)$ and $d p_{f}^{h} / d t=0$.

3. Accommodation: If $t \geq t^{* *}$, there are two possible sub-cases of accommodating behavior. a) Following Brander and Spencer(1981, p. 379), whenever there exists an interval $t^{* *} \leq t<\bar{t}$ such that the foreign firm accommodates with positive output, then $p_{f}^{h}\left(S_{f}^{h}\left(t^{* *}\right), S_{h}^{h}\left(t^{* *}\right)\right)>p_{f}^{h}\left(B_{f}^{h}, 0\right)$ and $d p_{f}^{h} / d t>0$. b) Whenever $t \geq t^{* *}$ and $t \geq \bar{t}$ such that the foreign firm accommodates with an output equal to zero, then $p_{f}^{h} \geq p_{f}^{h}\left(0, M_{h}^{h}\right)$, which is independent of $t$. Further, $p_{f}^{h}\left(B_{f}^{h}, 0\right) \geq p_{f}^{h}\left(0, M_{h}^{h}\right)$ if and only if $t^{* *} \geq \bar{t}$.

(Proof: see Appendix I) 


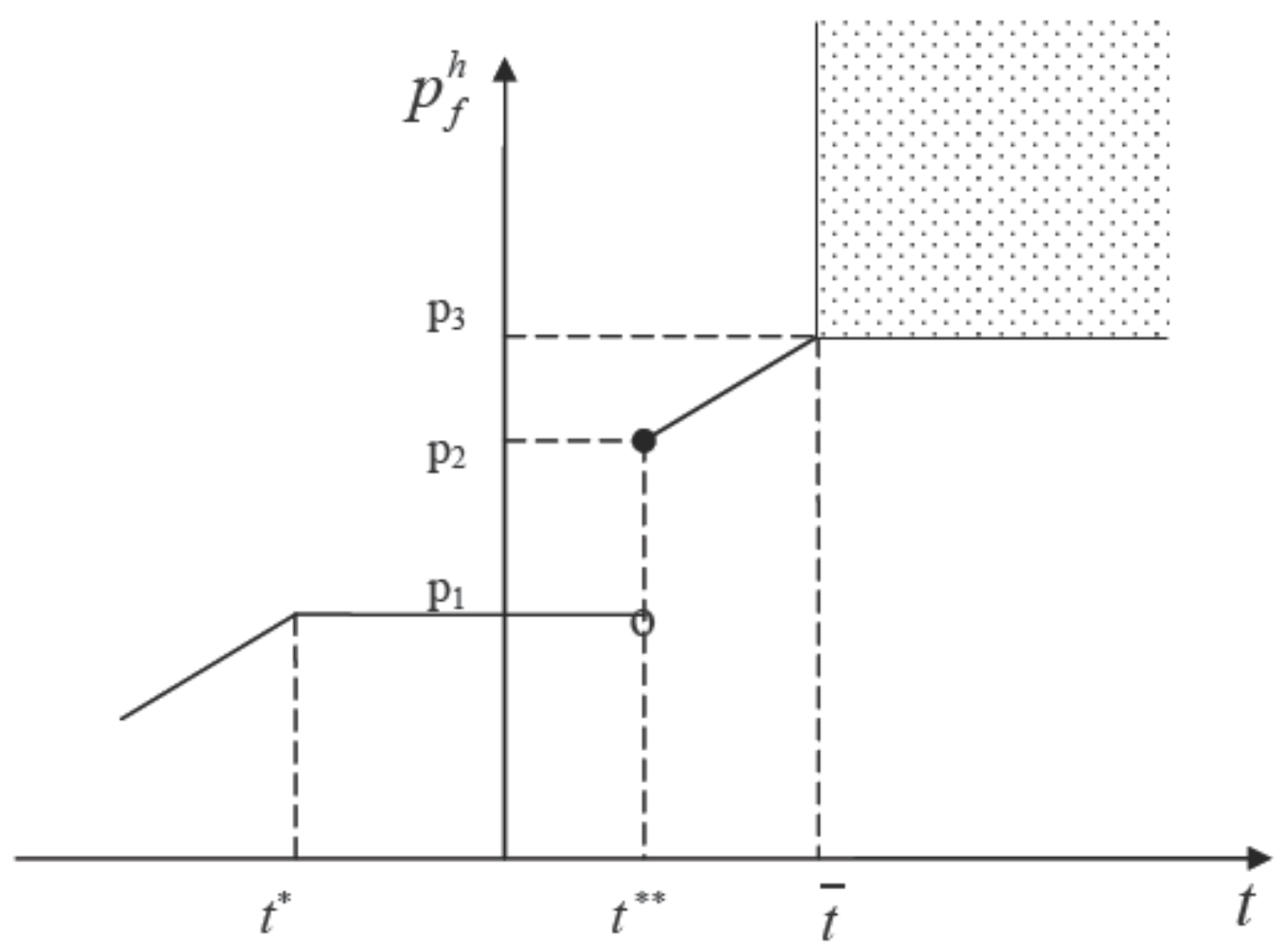

Figure 5: The impact of tariffs on the price of foreign product

Fig. 5 establishes the relation between the price of the foreign product and the tariff for the case where $t^{* *}<\bar{t}$. For a small tariff less than $t^{*}$, the foreign firm monopolizes the home market, and the price is less than $p_{1}$. As the tariff rises, the monopoly output falls, the price rises, and the foreign firm's profits fall. When $t$ reaches $t^{*}$, the home firm would be able to enter the home market with a positive output if the foreign firm continues with its monopoly output and price. Consequently, the foreign firm produces slightly more than the limit output and charges a price equal to $p_{1}$ to preempt participation by the home firm. Further increases in the tariff leaves the foreign firm's output unchanged and its price constant at $p_{1}$, but its profitability continues to decline. When the tariff reaches $t^{* *}$, it becomes more profitable for the foreign firm to accommodate participation by the home firm. Thus, there is a discrete decline in the foreign firm's output. In the case shown in Fig 5, where $\bar{t}>t^{* *}$, the foreign firm's Stackelberg leadership output remains positive at $t^{* *}$ and there is a discrete jump in the price to $p_{2}$. Yet, further increases in the tariff reduce the Stackelberg leadership output and increase the price. Profits also fall. When the tariff reaches $\bar{t}$, the Stackelberg leadership output is equal to zero, which implies that the prices are greater than or equal to $p_{3}$. The appendix shows that broadly similar results can be obtained for the price-leadership model. 


\section{Dumping versus Predation}

As we have seen, dumping is defined to exist when a firm in one country exports its product to another country at a price below that which it normally charges in its own country (pricebased dumping) or below its average costs of production (cost-based dumping). For the most part, we will focus on price-based dumping. Price-based dumping is said to occur whenever the dumping margin,

$$
D=p_{f}^{f}+\tau-p_{f}^{h},
$$

is positive. In other words, dumping exists if the foreign firm charges lower price on the home market than the price on its own market adjusted for transport costs. If dumping is detected, the home country is usually able to impose an antidumping duty. ${ }^{11}$

We consider two types of antidumping duties. First, we define a standard or partial antidumping duty, $t^{\text {padd }}=D(t=0)$, which is equal to the dumping margin when the tariff is equal to zero. Second, we define a sophisticated or full antidumping duty, $t^{\text {fadd }}$, to be the minimum tariff that would generate a dumping margin that is less than or equal to zero. ${ }^{12}$ While full antidumping duties are attractive from a theoretical standpoint, almost all antidumping duties that are implemented in practice are, at least initially, partial antidumping duties. $^{13}$

\footnotetext{
${ }^{11}$ In addition to a positive dumping margin, authorities must also show that there is material injury or a threat of material injury to the home industry. In practice, a `But-For' approach is generally used to define material injury. In this approach, the authority conducts a counter-factual analysis to compare conditions of the targeted industry in the presence of dumped goods with an estimate of conditions of the industry without such goods. Material injury is said to exist when the targeted home industry would have been better off 'but for' the sales of dumped commodities. In our model, material injury always occurs because the home firm would have enjoyed monopoly profit if the foreign firm did not participate. Hence, we assume that antidumping duties are always allowable if the dumping margin is positive.

${ }^{12}$ In the model, there are some situations where there will be a single tariff, or a range of tariffs, that result in a dumping margin exactly equal to zero, but in other situations, the smallest tariff that stops dumping leads to a negative dumping margin.

${ }^{13}$ The antidumping authority may periodically review the situation and increase the duty if it finds that dumping persists in spite of the initial duty. Such an iterative reviewing and resetting procedure may, in some situations, approximate a full antidumping duty.
} 
Dumping and predation depend on different criteria. Predation hinges on the relationship between the limit output, $B_{f}^{h}$, and the trigger output, $Z_{f}^{h}$, in accordance with Prop. 1 . Consequently, the predation criterion depends on the cost parameters of both firms and demand parameters of the home market. While the demand parameters of the foreign market are irrelevant to predation, they have a role in the price comparison that comprises the dumping criterion. This observation leads to the following proposition.

Proposition 4 Dumping and predation are separate and distinct matters:

1. Dumping and predation may coexist.

2. Predation may occur when dumping does not.

3. Dumping may occur when predation does not.

4. Neither dumping nor predation may occur.

Proof: The proof is straightforward. In Prop. 4, if $M_{f}^{h} \leq B_{f}^{h}<Z_{f}^{h}$, then predation occurs. Since the dumping margin includes the foreign price, $p_{f}^{f}\left(M_{f}^{f}\right)$, we have $D=p_{f}^{f}\left(M_{f}^{f}\right)+\tau-p_{f}^{h}\left(B_{f}^{h}+\varepsilon\right)$, which could be greater or less than zero. Thus, when predation occurs, dumping may or may not occur, establishing in the situations 1 and 2 . Similarly, if $Z_{f}^{h} \leq B_{f}^{h}$, then predation does not occur. The dumping margin, $D=p_{f}^{f}\left(M_{f}^{f}\right)+\tau-p_{f}^{h}\left(S_{f}^{h}, S_{h}^{h}\right)$, once again, could be greater or less than zero, which establishes situation 3 and $4 . \Delta$

Tab. 1 summarizes situations in Prop. 4, and also invites further consideration of the situation where the dumping and predation coexist. 
Table 1: predation, dumping, and antidumping duties

\begin{tabular}{|c|c|c|c|}
\hline & & \multicolumn{2}{|c|}{ Predation } \\
\hline & & Yes & No \\
\hline $\begin{array}{l}\mathrm{u} \\
\mathrm{m}\end{array}$ & Yes & $\begin{array}{l}\text { Situation 1: An anti-dumping duty may } \\
\text { or may not prevent predation }\end{array}$ & $\begin{array}{l}\text { Situation 2: An anti-dumping duty may } \\
\text { appears despite no predation }\end{array}$ \\
\hline n & No & $\begin{array}{l}\text { Situation 3: No dumping duty to } \\
\text { prevent predation }\end{array}$ & $\begin{array}{l}\text { Situation 4: No dumping duty and no } \\
\text { predation }\end{array}$ \\
\hline
\end{tabular}

Proposition 5 Suppose that dumping and predation coexist when $t=0$.

1. A standard or partial antidumping duty will lead to accommodation if and only if it happens to exceed the anti-predation tariff, $t^{* *}$.

2. A sophisticated or full antidumping duty always leads to accommodation.

Proof: The first part of proposition follows immediately from Prop. 2. Next, the full antidumping tariff, $t^{\text {fadd }}$, is by definition the minimum tariff such that $D \leq 0$. Since there is predation when $t=0$, we have $t^{*}<0<t^{* *}$. Since $p_{f}^{f}$ is always independent of $t$ and $p_{f}^{h}$ is constant for all values of $t$ such that $t^{*} \leq t<t^{* *}$ by Prop. 3, it follows from Eq. (17) the dumping margin is constant as well. Consequently, if there is dumping when $t=0$, then dumping persists so long as $t<t^{* *}$, which establishes that $t^{\text {fadd }}$ is greater than or equal to $t^{* *}$. $\Delta$

Overall, these results suggest that antidumping policies cannot be justified on the basis of preventing predatory behavior by foreign firms. In accordance with Prop. 4, antidumping duties are permissible in some situations where there is no predation, and predation may exist in other situations where antidumping duties are not permissible. Even when dumping and predation coexist, Prop. 5 implies that a partial antidumping duty may either be too small to prevent predation or unnecessarily large. Finally, if predation and dumping coexist in the initial zero-tariff equilibrium, a full antidumping duty will prevent predation, but it may be 
unnecessarily large in the sense of being greater than $t^{* *}$. Further, full antidumping duties appear to be of limited practical importance in this context because of calculation difficulties. $^{14}$

Similar results apply in the case of cost-based dumping. Suppose that the foreign firm has no sales in its own country so that the price-based dumping criterion cannot be used. Rather than being based on the price of the foreign firm on its own market, the dumping margin given by Eq. (17) is now based on the average cost of exporting to be $c_{f}+\tau+\left[\psi_{f}^{h}+\phi_{f}\right] / q_{f}^{h}$, where $\psi_{f}^{h}$ represents the sunk costs of the foreign firm. Since the foreign firm's average cost of exporting depends on its participation and sunk costs, the cost-based dumping criterion differs qualitatively from the predation criterion. Consequently, Prop. 4 and Prop. 5 go through for cost-based dumping as well as price-based dumping. Appendix II indicates that there is a similar non-equivalence between anti-predation tariffs and antidumping duties in a priceleadership game.

\section{Welfare Analysis}

It is important to consider whether predatory behavior by the foreign firm necessarily reduces welfare in the home country. The home country's quasi-linear utility function, which generates the simple linear demand system given by Eqs. (1) and (2), can be written as:

$$
U=u\left(q_{f}^{h}, q_{h}^{h}\right)+q_{0}
$$

\footnotetext{
${ }^{14}$ It is apparent from Eq. (17) that an antidumping duty may be applied in a situation where the foreign firm monopolizes the home market in an initial zero-tariff situation. While foreign monopoly and predation are mutually-exclusive states that are connected in accordance with Prop. 1, foreign monopoly as well as predation is separate and distinct from dumping. Consequently, even if foreign monopoly and dumping happen to coexist, a partial antidumping duty may be less than or equal to $t^{*}$ as well as $t^{* *}$. This implies that a partial antidumping duty may not eliminate foreign monopoly. If monopoly does happen to be eliminated, predation may persist. Finally, even if predation is eliminated, the duty may be unnecessarily large. While this implies that the central tenet of the first part of Prop. 5 remains in force, the second part breaks down. Starting from a position of foreign monopoly where $t^{*}>0$, a full antidumping duty may not be sufficient to cause accommodating behavior. Under foreign monopoly, a tariff raises the foreign firm's price and may eliminate the dumping margin before the anti-monopoly tariff $t^{*}$ is reached. Thus, foreign monopoly may persist, and accommodation may not occur.
} 
where $q_{0}$ is the consumption of a competitive numeraire good. ${ }^{15}$ Quasi-linear utility is useful because there are no income effects and inverse demand functions arise directly from partial differentiation.

$$
\begin{aligned}
& p_{f}^{h}=\frac{\partial u\left(q_{f}^{h}, q_{h}^{h}\right)}{\partial q_{f}^{h}} \\
& p_{h}^{h}=\frac{\partial u\left(q_{f}^{h}, q_{h}^{h}\right)}{\partial q_{h}^{h}}
\end{aligned}
$$

Under predation where $q_{f}^{h} \cong B_{f}^{h}$ and $q_{h}^{h}=0$, the home country's welfare, $W_{B}$, depends on tariff revenue and the consumer surplus from the foreign good alone. Meanwhile, under accommodation where $q_{f}^{h}=S_{f}^{h}$ and $q_{h}^{h}=S_{h}^{h}$, the home country's welfare, $W_{S}$, is obtained from tariff revenue, the profits of the home firm, and consumer surplus from both products. ${ }^{16}$

$$
\begin{aligned}
W_{B}(t) & =u\left(B_{f}^{h}, 0\right)-\left[p_{f}^{h}\left(B_{f}^{h}, 0\right)-t\right] B_{f}^{h}=u\left(B_{f}^{h}, 0\right)-\pi_{f}^{h}\left(B_{f}^{h}, 0, t\right)-\left[c_{f}+\tau\right] B_{f}^{h} \\
& W_{S}(t)=u\left(S_{f}^{h}(t), S_{h}^{h}(t)\right) \\
- & {\left[p_{f}^{h}\left(S_{f}^{h}(t), S_{h}^{h}(t)\right)-t\right] S_{f}^{h}(t)-p_{h}^{h}\left(S_{f}^{h}(t), S_{h}^{h}(t)\right) S_{h}^{h}(t)+\pi_{h}\left(S_{f}^{h}(t), S_{h}^{h}(t)\right) } \\
= & u\left(S_{f}^{h}(t), S_{h}^{h}(t)\right)-\pi_{f}^{h}\left(S_{f}^{h}(t), S_{h}^{h}(t), t\right)-\left[c_{f}+\tau\right] S_{f}^{h}-c_{h} S_{h}^{h}-\phi_{h}
\end{aligned}
$$

Taking the difference between home-country welfare under predation versus accommodation and adding and subtracting $\left[c_{f}+\tau\right] S_{h}^{h}$ yields:

$$
\begin{array}{r}
W_{B}(t)-W_{S}(t)=\left\{\left[u\left(B_{f}^{h}, 0\right)-u\left(S_{f}^{h}(t), S_{h}^{h}(t)\right)\right]-\left[c_{f}+\tau\right]\left[B_{f}^{h}-S_{f}^{h}-S_{h}^{h}\right]\right\} \\
\quad+\left\{\left[c_{h}-\left[c_{f}+\tau\right]\right] S_{h}^{h}\right\}+\left\{\pi_{f}^{h}\left(S_{f}^{h}(t), S_{h}^{h}(t), t\right)-\pi_{f}^{h}\left(B_{f}^{h}, 0, t\right)\right\}+\phi_{h}(23)
\end{array}
$$

To assist with welfare comparisons, we define a benchmark situation where: (a) the high boundary tariff for an internal Stackelberg equilibrium exceeds the anti-predation tariff such

\footnotetext{
${ }^{15}$ While we could write $u\left(q_{f}^{h}, q_{h}^{h}\right)=\alpha q_{f}^{h}+\theta q_{h}^{h}-\frac{1}{2}\left[\beta\left(q_{f}^{h}\right)^{2}+2 \gamma q_{f}^{h} q_{h}^{h}+\sigma\left(q_{h}^{h}\right)^{2}\right]$, we do not need the specific function form to derive our results.

${ }^{16}$ Consumer surplus equals the area below the Marshallian demand function minus costs of purchasing goods.
} For example, under predation, consumer surplus is

$$
\int_{0}^{B_{f}^{h}} \frac{\partial u\left(q_{f}^{h}, 0\right)}{\partial q_{f}^{h}} d q_{f}^{h}+\int_{0}^{0} \frac{\partial u\left(B_{f}^{h}, q_{h}^{h}\right)}{\partial q_{h}^{h}} d q_{h}^{h}-p_{f}^{h} B_{f}^{h}=u\left(B_{f}^{h}, 0\right)-p_{f}^{h} B_{f}^{h} .
$$


that $\bar{t} \geq t^{* *}$, (b) the foreign firm has a cost advantage in the sense that $c_{f}+\tau \leq c_{h}$ and (c) the goods are perfect substitutes such that $\alpha=\theta$ and $\beta=\sigma=\gamma$.

We begin with a comparative welfare result that is similar to Brander and Spencer (1981, p. 380).

Proposition 6 (Brander and Spencer) Ceteris paribus, home-country welfare may (or may not) be higher if the foreign firm were to choose predation rather than accommodation such that $W_{B}(t)-W_{S}(t)$ may (or may not) be positive.

Proof: In addition to the benchmark conditions, consider a tariff, $t$, in the neighborhood of $t^{* *}$. With $\bar{t} \geq t^{* *}$, we have the accommodation price for the foreign firm greater than its predation price by Prop. 3 such that $p_{f}^{h}\left(S_{f}^{h}, S_{h}^{h}\right) \geq p_{f}^{h}\left(B_{f}^{h}, 0\right)$. Since the goods are perfect substitutes, this implies that $B_{f}^{h} \geq S_{f}^{h}+S_{h}^{h}$ and thus $u\left(B_{f}^{h}, 0\right) \geq u\left(S_{f}^{h}, S_{h}^{h}\right)$. Further, under imperfect competition, the increment to utility from consuming $B_{f}^{h}-\left[S_{f}^{h}+S_{h}^{h}\right]$ additional goods is greater than the increment to cost from producing them. This makes the terms within the first set of curly brackets in Eq.(23) greater than or equal to zero. Next, we observe that the terms in the second set of curly brackets are greater than or equal to zero if the foreign firm has a cost advantage. Further, for an tariff in the vicinity of $t^{* *}$, the profit of the foreign firm are approximately equal under predation and accommodation making the terms in the third set of curly brackets approximately equal to zero. Since we have $\phi_{h}>0$, it now follows that welfare is higher if the foreign firm chooses predation because $W_{B}-W_{S}>0$. Finally, this inequality can clearly be reversed by sufficiently large departures from the benchmark conditions (a)-(c) or tariffs sufficiently smaller than $t^{* *} . \Delta$

Of course, the foreign firm, not the home country, chooses whether there will be a state of accommodation, predation, or indeed, foreign monopoly. Now suppose that the foreign firm would choose predation when the home-country tariff is set equal to zero. From Prop. 2, the home country could prevent predation by imposing its anti-predation tariff, $t^{* *}$. Consequently, it is important to compare home-country welfare under predation with a tariff equal to zero with welfare under accommodation with a tariff equal to $t^{* *} . \Delta$ 
Proposition 7 National welfare under the predation regime at the zero tariff may (or may not) be higher than under the accommodation regime at the anti-predation tariff such that $W_{B}(t=0)-W_{S}\left(t=t^{* * *}\right)$ may (or may not) be greater than zero.

Proof: We can write $W_{B}(0)-W_{S}\left(t^{* *}\right)=\left\{W_{B}(0)-W_{B}\left(t^{* *}\right)\right\}+\left\{W_{B}\left(t^{* *}\right)-W_{S}\left(t^{* *}\right)\right\}$. From the proof of Prop. 6, $W_{B}\left(t^{* *}\right)-W_{S}\left(t^{* *}\right) \geq \phi_{h}>0$ in the benchmark situation. Since we have $d W_{B} / d t=B_{f}^{h}>0$ from Eq. (21), it follows that $W_{B}(0)-W_{B}\left(t^{* *}\right)=-t^{* *} B_{f}^{h}$. For parameter values where $t^{* *}$ is sufficiently small, $\phi_{h}>t^{* *} B_{f}^{h}$ making welfare higher under predation without a tariff than in a Stackelberg equilibrium with a tariff equal to $t^{* *}$. Either deviations from the benchmark conditions or larger values of $t^{* *}$ can clearly lead to greater welfare under accommodation with the anti-predation tariff. $\Delta$

In Appendix I, we extend these results by showing that the home country may be better off assessing its best tariff consistent with predation rather than its best tariff consistent with accommodation. While countries may wish to prevent predation on producer-fairness grounds, Prop. 7 implies that preventing predation is not necessarily in the national interest.

\section{Conclusion}

This paper investigates the relation between antidumping duties and predatory behavior by foreign firms in a context that is new to the literature. The prior literature on predatory dumping emphasizes multi-period models where future monopolization, or at least increased market share is the motivation for predation in the present period. For example, in Eaton and Mirman (1991) the foreign firm is able to exploit asymmetric information concerning its own market, while in Hartigan (1996) the home firm is vulnerable to predation due to the financial market imperfections. By contrast, we show that predation can arise in a simple one-shot game with perfect information that adapts the Stackelberg entry deterrence framework developed by Dixit (1979) and Brander and Spencer (1981). In this setting, the foreign firm is a first mover and, under some conditions, may use its leadership position to force the home firm out of the market.

Antidumping duties, however, turn out to be a dubious weapon for combating such predation. We show that under some circumstances, an antidumping duty is implemented in the absence of predation, and under other circumstances, no dumping duty will be imposed in the presence 
of predation. Even when the underlying conditions favor predation by foreign firms and governments do impose antidumping duties on foreign goods, simple duties, which are typically used in practice, may not be sufficient to preclude predation. Further, while sophisticated duties, which are designed to eliminate dumping, are sufficient to prevent dumping, such duties are generally larger than necessary. Although there is no substantial evidence that predation by foreign firms is widespread in reality, the results of our modeling, thus, suggest that antidumping duties cannot be justified as a policy mechanism to prevent predation. While antidumping duties are supposed to offset unfair pricing practices by foreign firms, they generally punish foreign firms for activities such as price discrimination and selling below costs, which are generally both acceptable and legal for home firms.

We also extend welfare analysis in Brander and Spencer (1981) to address two new issues. First, we find that home-country welfare may be higher if the foreign firm were to choose predation rather than accommodation. Second, we show that, even when the foreign firm would choose predation, the home country does not inevitably gain by imposing an antipredation tariff, which induces accommodating behavior by the foreign firm. Consequently, while preventing predation always serves the interest of the home firms, it does not always necessarily serve the national interest.

The model could be adapted to incorporate tariffs that are contingent on the presence of either predation or dumping. This would allow somewhat richer profit-maximizing behavior on the part of the foreign firm since it could exempt itself from tariffs by choosing not to predate on the one hand or dump on the other hand. ${ }^{17}$ Nevertheless, it appears that our key qualitative results will continue to hold because the differences between the predation versus dumping criteria will continue to lead to separate and distinct anti-predation versus anti-dumping tariffs.

The model could also be extended to allow a repeated-game structure. Suppose that the home firm's participant-status lapses if it remains out of the market for a sufficient duration. On the one hand, depending on its expectations of future market and cost parameters, there may be an added incentive for the home firm to participate in the present period so as to maintain its status. On the other hand, the prospect of future monopolization is likely to provide additional incentive for present predation by the foreign firm. Further, the possibility of future

\footnotetext{
${ }^{17}$ Indeed, with appropriate contingent tariffs set by the government, the foreign firm would choose not to predate or dump and, thus, would be exempt from tariff charges.
} 
monopolization complicates the national welfare picture for the home country and it appears to make it more likely that preventing predation would be in the national interest.

While current antidumping policies are poorly designed for handling predation by foreign firms, the prognosis for policy reform remains problematic. Detecting truly predatory behavior by any firms, whether home or foreign, is typically very difficult in practice. In the international arena, it may be hard to differentiate between situations of foreign monopoly and foreign predation. For example, it may be politically and economically difficult to establish whether a home firm is no longer viable given the current market and cost conditions. Once predation has been detected, there is not a straightforward formula for the anti-predation tariff even in the simple world of linear demands and constant costs, which we model. This suggests that to the extent that trade policy has a role in fighting predation by foreign firms, import quotas may be more appropriate instruments than tariffs. ${ }^{18}$ More broadly, the regular instruments of competition policy seem likely to be a better first-line of defense against foreign as well as home predation. Trade policy measures could simply be held in reserve in the case of non-compliance by the foreign firms.

\footnotetext{
${ }^{18}$ For example, suppose $Z_{f}^{h}>B_{f}^{h}$ so that the predation would occur in the quantity game. Predation would be forestalled without having to accurately determine $Z_{f}^{h}$ if an import quota were set anywhere between $S_{f}^{h}$ and $B_{f}^{h}$. In the price-leadership game, the similar argument might be made in favor of floor prices rather than tariffs.
} 


\section{Appendix}

\section{Appendix I: The Quantity-Leadership Game; Further Details}

\section{Proof of Lemma 1}

We begin with the derivation of Eq. (16) using a three-step procedure: (i) we determine the Stackelberg profit level of the foreign firm by substituting the Stackelberg quantities into Eq. (4), (ii) we then insert this profit level back into Eq. (4) to determine the equation for the Stackelberg iso-profit curve, and (iii) we finally set $q_{h}^{h}$ equal to zero and solve for $q_{f}^{h}$ using the quadratic formula. The details of this calculation are shown in the appendix. Note that the variable profit for the foreign firm selling in the home market, $\pi_{f}^{h}\left(q_{f}^{h}, q_{h}^{h}\right)$, is equal to $\left\{p_{f}^{h}\left(q_{f}^{h}, q_{f}^{h}\right)-\left[c_{f}+\tau+t\right]\right\} q_{f}^{h} \quad$ in accordance with Eq. (4). By definition, $\pi_{f}^{h}\left(Z_{f}^{h}, 0\right)=\pi_{f}^{h}\left(S_{f}^{h}, S_{h}^{h}\right)$. According to Eq. (1), $\left\{\left[\alpha-\beta Z_{f}^{h}\right]-\left[c_{f}+\tau+t\right]\right\} Z_{f}^{h}=\pi_{f}^{h}\left(S_{f}^{h}, S_{h}^{h}\right)$ or $\beta\left[Z_{f}^{h}\right]^{2}-\left\{\alpha-\left[c_{f}+\tau+t\right]\right\} Z_{f}^{h}+\pi_{f}^{h}\left(S_{f}^{h}, S_{h}^{h}\right)=0$. Since the trigger output is the higher output of the two intersections between the Stackelberg iso-profit contour and the horizontal axis, we solve this quadratic equation to obtain $Z_{f}^{h}=\frac{\left\{\alpha-\left[c_{f}+\tau+t\right]\right\}+\sqrt{\left[\alpha-\left[c_{f}+\tau+t\right]^{2}-4 \beta \pi_{f}^{h}\left(S_{f}^{h}, S_{h}^{h}\right)\right.}}{2 \beta}$. Since $M_{f}^{h}=\frac{\alpha-\left[c_{f}+\tau+t\right]}{2 \beta}$ in Eq. (8), it follows that $Z_{f}^{h}=M_{f}^{h}+\sqrt{\left[M_{f}^{h}\right]^{2}-\pi_{f}^{h}\left(S_{f}^{h}, S_{h}^{h}\right) / \beta}$. (i) When $t \geq \bar{t}, S_{f}^{h}=0$ in accordance with Eq. (14) and thus $\pi_{f}^{h}\left(S_{f}^{h}, S_{h}^{h}\right)=0$, we obtain $Z_{f}^{h}=2 M_{f}^{h}$. (ii) When $\underline{t} \leq t \leq \bar{t}$, we obtain $Z_{f}^{h}=M_{f}^{h}+\sqrt{\left[M_{f}^{h}\right]^{2}-\frac{2 \sigma\left\{\alpha-\left[c_{f}+\tau\right]\right\}-2 \sigma \beta S_{f}^{h}-\gamma\left[\theta-\gamma S_{f}^{h}-c_{h}\right]}{2 \sigma \beta} S_{f}^{h}}$ according to Eqs. (4) and (7). Using Eq. (12) and simplifying the above equation yields $Z_{f}^{h}=M_{f}^{h}+\sqrt{\left[M_{f}^{h}\right]^{2}-\left[1-\frac{\gamma^{2}}{2 \beta \sigma}\right]\left[S_{f}^{h}\right]^{2}}$. (iii) When $2 \beta\left[\mu-\bar{q}_{f}^{h}\right] \leq t \leq \underline{t}, S_{f}^{h}=\bar{q}_{f}^{h}$ and $S_{h}^{h}=0$. Given that $\pi_{f}^{h}\left(Z_{f}^{h}, 0\right)=\pi_{f}^{h}\left(\bar{q}_{f}^{h}, 0\right)$, it immediately follows that $Z_{f}^{h}=S_{f}^{h}=\bar{q}_{f}^{h}$. (iv) When $t \leq 2 \beta\left[\mu-\bar{q}_{f}^{h}\right], \quad S_{f}^{h}=M_{f}^{h}$ and $S_{h}^{h}=0$. By definition, $\pi_{f}^{h}\left(Z_{f}^{h}, 0\right)=\pi_{f}^{h}\left(M_{f}^{h}, 0\right)$ and thus $Z_{f}^{h}=M_{f}^{h} \cdot \Delta$ 


\section{Proof of Lemma 1}

Continuity follows directly from Eq. (16). We consider monotonicity in two steps. First, differentiating Eq. (16) on the interval $\underline{t}<t \leq \bar{t}$ and using Eqs. (8) and (14), we obtain $\frac{d Z_{f}^{h}}{d t}=\frac{d M_{f}^{h}}{d t}+\frac{1}{2}\left[\left[M_{f}^{h}\right]^{2}-\left[1-\frac{\gamma^{2}}{2 \beta \sigma}\right]\left[S_{f}^{h}\right]^{2}\right]^{-\frac{1}{2}}\left[2 M_{f}^{h} \frac{d M_{f}^{h}}{d t}-2 S_{f}^{h} \frac{d S_{f}^{h}}{d t}\left[1-\frac{\gamma^{2}}{2 \beta \sigma}\right]\right]$. This can be rewritten $\quad$ as $\quad \frac{d Z_{f}^{h}}{d t}=-\frac{1}{2 \beta}+\frac{1}{2}\left[\left[M_{f}^{h}\right]^{2}-\left[1-\frac{\gamma^{2}}{2 \beta \sigma}\right]\left[S_{f}^{h}\right]^{2}\right]^{-\frac{1}{2}}\left[S_{f}^{h}-M_{f}^{h}\right] / \beta$, or $\frac{d Z_{f}^{h}}{d t}=\frac{1}{2 \beta}\left[\left[M_{f}^{h}\right]^{2}-\left[1-\frac{\gamma^{2}}{2 \beta \sigma}\right]\left[S_{f}^{h}\right]^{2}\right]^{-\frac{1}{2}}\left[M_{f}^{h}-Z_{f}^{h}+S_{f}^{h}-M_{f}^{h}\right]$. After simplification, we obtain $\frac{d Z_{f}^{h}}{d t}=\frac{1}{2 \beta}\left[S_{f}^{h}-Z_{f}^{h}\right] /\left[Z_{f}^{h}-M_{f}^{h}\right]$. Since $Z_{f}^{h}$ is greater than either $S_{f}^{h}$ or $M_{f}^{h}$ whenever there is a Stackelberg equilibrium on the interval $\underline{t}<t \leq \bar{t}$, it follows that $\frac{d Z_{f}^{h}}{d t}<0$. Second, differentiating Eq. (16) over the interval where $\bar{t} \leq t<2 \beta \mu$ and $M_{f}^{h}$ is positive, we obtain $\frac{d Z_{f}^{h}}{d t}=-1 / \beta$, which is less than zero. $\Delta$

\section{Proof of Prop. 2}

From Eq. (11), we have $0<B_{f}^{h}<\bar{q}_{f}^{h}$ with $B_{f}^{h}$ independent of $t$. To establish the first part of the proposition, we deduce from Eq. (8) that $M_{f}^{h}=0$ when $t=2 \beta \mu$ and that in the limit as $t$ approaches $2 \beta\left[\mu-\bar{q}_{f}^{h}\right]$ from above, $M_{f}^{h}=\bar{q}_{f}^{h}$. Since $M_{f}^{h}$ is continuous in $t$, we know that there exists $t^{*}$ such that $M_{f}^{h}\left(t^{*}\right)=B_{f}^{h}$. Further, since $M_{f}^{h}(t)$ decreases linearly in $t$ such that $d M_{f}^{h} / d t=-1 /[2 \beta]<0$, it follows that $t^{*}$ is unique. If and only if $t \geq t^{*}$, we have $B_{f}^{h} \geq M_{f}^{h}$, and thus monopoly is eliminated in accordance with Prop. 1.

Turning to the second part of the proposition, we know from Lemma 1 that $Z_{f}^{h}$ continuously decreases from $\bar{q}_{f}^{h}$ to 0 over the interval $\underline{t}<t<2 \beta \mu$. Consequently, there exists a unique $t^{* *}$ such that $Z_{f}^{h}(t)=B_{f}^{h}$. If and only if $t \geq t^{* *}$ we have $B_{f}^{h} \geq Z_{f}^{h}$, and thus predation is eliminated in accordance with Prop. 1. Finally, since we have $B_{f}^{h}=Z_{f}^{h}\left(t^{* *}\right)>M_{f}^{h}\left(t^{* *}\right)$ and $d M_{f}^{h} / d t$ is negative, it follows that $t^{*}$ must be less than $t^{* *}$ to obtain $M_{f}^{h}\left(t^{*}\right)=B_{f}^{h}$. $\Delta$ 


\section{Proof of Prop. 3}

1. If $t<t^{*}$, then by Prop.2, the foreign firm monopolizes the market, and $q_{h}^{h}=0$. Since $d M_{f}^{h} / d t=-\frac{1}{2 \beta}<0$ in accordance with Eq. (8), we obtain $d p_{f}^{h} / d t=1 / 2>0$ from Eq. (1).

2. If $t^{*} \leq t<t^{* *}$, then by Prop.2, the foreign firm preempts participation and produces a quantity slightly larger than $B_{f}^{h}$ with $q_{h}^{h}$ remaining equal to zero. Consequently, $p_{f}^{h}=\alpha-\beta\left[B_{f}^{h}+\varepsilon\right]$, which is independent of $t$.

3. If $t \geq t^{* *}$, by Prop. 2 the foreign firm accommodates participation. For sub-case a), we follow Brander and Spencer (1981, p. 379). When $t^{* *} \leq t<\bar{t}$, Prop. 2 implies there is accommodation, and Eq. (14) implies that the Stackelberg leadership output is strictly positive. When $t=t^{* *}$, the foreign firm would earn the same profits at the Stackelberg equilibrium as it would as lone firm with an output $B_{f}^{h}=Z_{f}^{h}\left(t^{* *}\right)$. Consequently, we can write: $\left[p_{f}^{h}\left(S_{f}^{h}, S_{h}^{h}\right)-\left[c_{f}+t+\tau\right]\right] S_{f}^{h}=\left[p_{f}^{h}\left(B_{f}^{h}, 0\right)-\left[c_{f}+t+\tau\right]\right] B_{f}^{h}$. Since the unit costs are the same and the definition of $t^{* *}$ implies that $B_{f}^{h}=Z_{f}^{h}\left(t^{* *}\right)>S_{f}^{h}\left(t^{* *}\right)$, it follows that $p_{f}^{h}\left(S_{f}^{h}\left(t^{* *}\right), S_{h}^{h}\left(t^{* *}\right)\right)>p_{f}^{h}\left(B_{f}^{h}, 0\right)$. Further, routine calculations using Eqs. (1), (12), and (13) reveal that $d p_{f}^{h} / d t=1 / 2>0$ for an internal Stackelberg equilibrium.

b) When $t \geq t^{* *}$ there is accommodation in accordance with Prop. 2 and when $t \geq \bar{t}$ the Stackelberg leadership quantity is equal to zero. In this boundary situation, the Stackelberg follower output is equal to $M_{h}^{h}$ in accordance with Eq. (15). Consequently, any price for the foreign good in the home market that is greater than or equal to $p_{f}^{h}\left(0, M_{h}^{h}\right)$ is consistent with the foreign firm staying out of the market. Since $M_{h}^{h}$ is independent of $t$ from Eq. (9), it follows that $p_{f}^{h}\left(0, M_{h}^{h}\right)$ is also independent of $t$. From Eq. (1), we obtain $p_{f}^{h}\left(B_{f}^{h}, 0\right)=\alpha-\beta B_{f}^{h} \quad$ under predation, and $p_{f}^{h}\left(0, M_{h}^{h}\right)=\alpha-\gamma M_{h}^{h}$ in the Stackelberg equilibrium where the leadership output is equal to zero. Consequently, $p_{f}^{h}\left(B_{f}^{h}, 0\right) \geq p_{f}^{h}\left(0, M_{h}^{h}\right)$ if and only if $B_{f}^{h} \leq \gamma M_{h}^{h} / \beta$. We know that when $t=\bar{t}$ the vertical intercept of the foreign firm's Cournot reaction function is $M_{h}^{h}$ and the horizontal intercept is $M_{f}^{h}(\bar{t})$. Given that the slope of the reaction function is always $d q_{f}^{h} / d q_{h}^{h}=-\gamma / 2 \beta$ from Eq. (6), 
it follows that $M_{h}^{h}=2 \beta M_{f}^{h}(\bar{t}) / \gamma$. Thus, we can now state $p_{f}^{h}\left(B_{f}^{h}, 0\right) \geq p_{f}^{h}\left(0, M_{h}^{h}\right)$ if and only if $B_{f}^{h} \leq 2 M_{f}^{h}(\bar{t})$. Using Eq. (16), we rewrite the second inequality as $B_{f}^{h} \leq Z_{f}^{h}(\bar{t})$. Since $Z_{f}^{h}\left(t^{* *}\right)=B_{f}^{h}$, if $\bar{t}=t^{* *}$ then $p_{f}^{h}\left(B_{f}^{h}, 0\right)=p_{f}^{h}\left(0, M_{h}^{h}\right)$. Since $Z_{f}^{h}(t)$ is declining in $t$ in accordance with Lemma $1, B_{f}^{h}=Z_{f}^{h}\left(t^{* *}\right)<Z_{f}^{h}(\bar{t})$, and $p_{f}^{h}\left(B_{f}^{h}, 0\right)>p_{f}^{h}\left(0, M_{h}^{h}\right)$ if and only if $\bar{t}<t^{* *} . \Delta$

\section{Further Welfare Results}

We can easily elaborate on section 6 in the text by comparing home-country welfare with an optimal tariff in the state of predation with welfare with an optimal tariff in the state of accommodation. To begin with, we maximize the home-country welfare under both predation and accommodation to determine these two optimal tariffs.

\section{Lemma 2}

1. Following Brander and Spencer (1981), the optimal tariff under predation is marginally lower than the anti-predation tariff, $t^{* *}$.

2. The optimal tariff under accommodation, $t^{S}$, is greater than or equal to the anti-predation tariff, $t^{* *}$.

Proof: The proof of the first part of the lemma is straightforward. Since $d M_{B} / d t=B_{f}^{h}>0$ in accordance with Eq. (21), home-country welfare is always increasing in $t$ under predation. Consequently, the optimal tariff under predation is the maximum of predation-consistent tariff, which is a tariff marginally lower than the anti-predation tariff, $t^{* *}$.

To prove the second part of the lemma, we maximize the home-country welfare under accommodation $W_{S}(t)$ subject to the inequality $t^{* *} \leq t$ according to Prop. 2. For simplicity consider the situation where (a) the high boundary tariff for an internal Stackelberg equilibrium exceeds the anti-predation tariff such that $\bar{t} \geq t^{* *}$, and (b) the goods are perfect substitutes such that $\alpha=\theta$ and $\beta=\sigma=\gamma$. After lengthy but routine calculations, we obtain $\frac{d W_{S}\left(t_{S}\right)}{d t}=\frac{3 \alpha-2\left[c_{f}+\tau\right]-c_{h}-10 t}{8 \beta}$ and $\frac{d^{2} W_{S}\left(t_{S}\right)}{d t^{2}}=-\frac{5}{4 \beta}<0$ using Eqs (1), (12), (13), and 
(22). There exists a unique tariff $t=\frac{3 \alpha-2\left[c_{f}+\tau\right]-c_{h}}{10}>0$ such that $\frac{d W_{S}\left(t_{s}\right)}{d t}=0$. Since this tariff does not depend on the participation cost of the home firm, $\phi_{h}$, it could be smaller or larger than the anti-predation tariff $t^{* *}$. Consequently, we could have an internal solution for the optimal tariff under accommodation such that $t^{S}>t^{* *}$, or boundary solution where $t^{S}=t^{* *} \cdot \Delta$

Corollary 5.1 National welfare with the optimal tariff under the predation regime may (or may not) be higher than welfare with the optimal tariff under the accommodation regime $t_{S}$ such that $W_{B}\left(t^{* *}\right)-W_{S}\left(t^{S}\right)$ may (or may not) be greater than zero.

Proof: We can write $W_{B}\left(t^{* *}\right)-W_{S}\left(t^{S}\right)=\left\{W_{B}\left(t^{* *}\right)-W_{S}\left(t^{* *}\right)\right\}+\left\{W_{S}\left(t^{* *}\right)-W_{S}\left(t^{S}\right)\right\}$. Prop. 6 establishes that in the benchmark situation, $W_{B}\left(t^{* *}-\varepsilon\right)-W_{S}\left(t^{* *}-\varepsilon\right) \geq \phi_{h}>0$. Meanwhile, the proof of Lemma 2 implies that under the benchmark conditions there is a value of the participation cost of the home firm, $\phi_{h}$, such that $t^{* *}=t^{S}$ and, thus, $W_{S}\left(t^{* *}\right)-W_{S}\left(t^{S}\right)=0$. Thus, $W_{B}\left(t^{* *}\right)-W_{S}\left(t^{S}\right)$ may be greater than zero. Sufficiently large deviations from any of the benchmark conditions or $t^{S}$ sufficiently larger than $t^{* *}$ can lead to greater welfare with the optimal tariff under accommodation. $\Delta$

\section{Appendix II: A Price-Leadership Game}

With other aspects of the model remaining the same, suppose there is now a price-leadership game where the foreign firm is still the leader and the home firm is still the follower. Fig. 6 illustrates simple geometric solutions for the home market. We focus on the area OFGK, where both firms sell positive quantities in the home market. The home firm, once again, has a discontinuous reaction function due to participation costs. In Fig. 6, FB and EWXY including the end points of both segments indicate the home firm's reaction function. Note that there is a kink at point $W$ on the home firm reaction function, where the foreign firm ceases to produce, because the home firm's iso-profit curve is vertical at this point. This contour intersects the $q_{f}^{h}=0$ line again above the right of the home firm's pure monopoly point $X$ as shown in Fig. 6. 


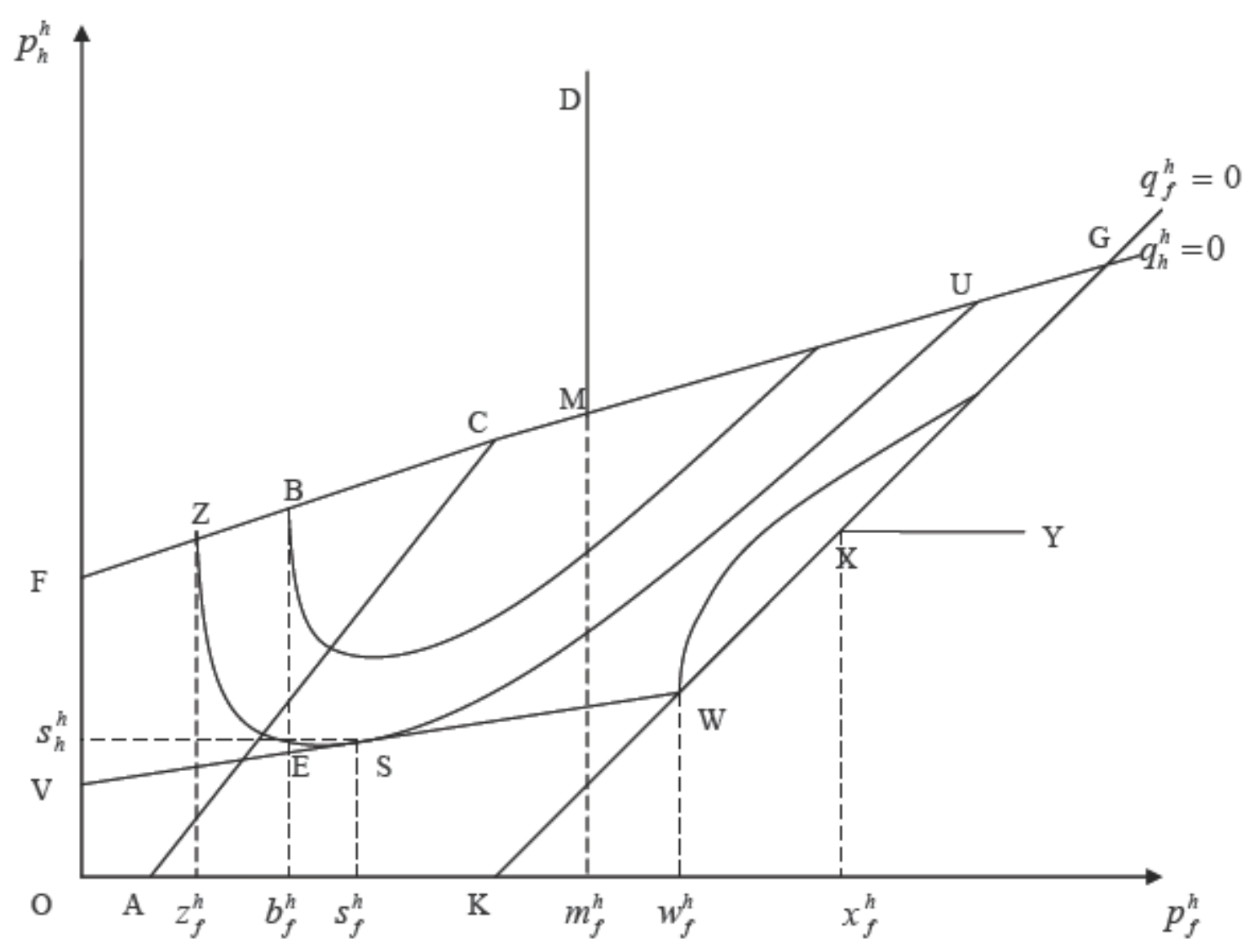

Figure 6: Reaction Functions

Depending on relative profitability, the foreign firm will monopolize the home market, preempt participation or accommodate participation.

Proposition 8 The equilibria under the price leadership are as follows:

1. Accommodation: If $b_{f}^{h} \leq z_{f}^{h}$, then the foreign firm accommodates participation and sets the leadership price at $s_{f}^{h}$, while the home firm sets the price at $s_{h}^{h}$.

2. Predation: If $z_{f}^{h}<b_{f}^{h} \leq m_{f}^{h}$, then the foreign firm preempts participation and sets the price marginally lower than the limit price, $b_{f}^{h}$.

3. Monopolization: If $b_{f}^{h}>m_{f}^{h}$, then the foreign firm monopolizes the home market and sets the monopoly price at $m_{f}^{h}$. 
Prop. 8 is clearly similar to Prop. 1. In addition, it is straightforward to show that there is still a well-defined anti-monopoly tariff and an anti-predation tariff. There is also a high boundary tariff $\bar{t}$, which would displace the Stackelberg point $S$ to point $W$ where the foreign firm's output is equal to zero. ${ }^{19}$ In addition, we can define a home-firm monopoly tariff, $\tilde{t}>\bar{t}$, which is just large enough to keep the foreign firm out of the market and allow the home firm to set the monopoly price. This leads to the following proposition describing the relation between the tariff $t$ and the price of the foreign product $p_{f}^{h}$.

Proposition 9 Changes in the tariff affect the price of the foreign product as follows:

1. Monopolization: If $t<t^{*}$, then we have $d p_{f}^{h} / d t>0$ with the foreign firm monopolizing the home market.

2. Predation: If $t^{*} \leq t<t^{* *}$, then the foreign firm preempts the participation of the home firm with $p_{f}^{h}=b_{f}^{h}-\varepsilon=m_{f}^{h}\left(t^{*}\right)$ and $d p_{f}^{h} / d t=0$.

3. Accommodation: If $t \geq t^{* *}$, there are three possible sub-cases of accommodating behavior: a) Whenever there exists an interval $t^{* *} \leq t<\bar{t}$, the foreign firm leads with a price that is consistent with strictly positive sales. Over this interval, $s_{f}^{h}\left(t^{* *}\right)>b_{f}^{h}$ and $\left.d s_{f}^{h} / d t>0 . \mathrm{b}\right)$ Whenever there exists an interval such that $\bar{t} \leq t<\tilde{t}$ and $t \geq t^{* *}$, the foreign firm leads with a price that implies zero sales but still requires the home firm's price to be less than its monopoly level. In this situation, $d s_{f}^{h} / d t>0$. Further, if $\bar{t} \leq t^{* *}<\tilde{t}$, then $s_{f}^{h}\left(t^{* *}\right)=b_{f}^{h}$. c) Whenever, $t \geq \tilde{t}$ and $t \geq t^{* *}$, the foreign firm leads with a price that implies zero sales and allows the home firm's price to be at its monopoly level. In this situation, $p_{f}^{h} \geq s_{f}^{h}(\tilde{t})=x_{f}^{h}$, which is independent of $t$. Further, $b_{f}^{h}>x_{f}^{h}$ if and only if $t^{* *} \geq \tilde{t}$.

Prop. 9 can be established by referring to Fig. 5. Because of the similarity between Prop. 9 and Prop. 3, the remaining analysis of the price-leadership game is analogous to the quantityleadership game and need not be repeated.

\footnotetext{
${ }^{19}$ There is also a low boundary tariff $\underline{t}$, which is necessarily negative that would induce the foreign firm to lead with the price that is sufficiently negative for the home firm to abandon the market even if its participation cost were equal to zero.
} 


\section{References}

Baldwin, Richard E. (1994) "The impact of the 1986 US-Japan Semiconductor Agreement", Japan and the World Economy, 6, 129-152.

Blonigen, Bruce A., Stephen E. Haynes (2002) "Antidumping Investigations and the PassThrough of Antidumping Duties and Exchange Rates", American Economic Review, 92 (4), 1044-1061.

Brander, A. James and Barbara J. Spencer (1981) "Tariffs and the extraction of foreign monopoly rents under potential entry", Canadian Journal of Economics, 14 (3), 371-389.

Dixit, Avinash (1979), "A Model of Duopoly Suggesting a Theory of Entry Barriers", Bell Journal of Economics, 10 (1), 20-32.

Eaton, J., and L.J. Mirman (1991) "Predatory dumping as signal jamming." In A. Takayama, M. Ohyama, and H. Ohta (eds.), Trade, Policy, and International Adjustments, (New York: Academic Press) 60-76.

Hartigan, J.C. (1994) "Dumping and signaling", Journal of Economic Behavior and Organization, 23, 69-81.

Hartigan, James C. (1996) "Predatory dumping", Canadian Journal of Economics, 29 (1), 228-239.

Prusa, Thomas J. (2001) "On the spread and impact of antidumping", Canadian Journal of Economics, 34, 591-611.

Viner, Jacob (1931) "Dumping". In the Encyclopedia of the Social Sciences. Vol. 5. New York: Macmillan.

World Trade Organization (WTO) "Statistics on antidumping". Available on the WTO website at: http://www.wto.org/english/tratop_e/adp_e/adp_e.htm. 